\title{
Treatment of Dementia in Parkinsonian Syndromes with Cholinesterase Inhibitors
}

\author{
Inga Liepelt ${ }^{\mathrm{a}}$ Walter Maetzler ${ }^{\mathrm{a}}$ Hans-Peter Blaicher ${ }^{\mathrm{b}}$ Thomas Gasser ${ }^{\mathrm{a}}$ \\ Daniela Berg ${ }^{\mathrm{a}}$ \\ ${ }^{a}$ Hertie Institute for Clinical Brain Research and ${ }^{b}$ Department of Psychiatry and Psychotherapy, \\ University of Tübingen, Tübingen, Germany
}

\section{Key Words}

Dementia $\cdot$ Parkinsonian syndromes $\cdot$ Cholinesterase inhibitor

\begin{abstract}
In Parkinsonian syndromes behavioural symptoms and dementia can be even more debilitating than motor symptoms and are an important predictor for nursing home placement and mortality. Neuropathologically, dementia seems to be primarily related to cortical changes rather than to subcortical alterations. Concerning neurotransmitter systems, the cholinergic system has been proposed to play a key role in cognitive disturbances. Based on studies with patients with Alzheimer disease, the application of cholinesterase inhibitors is vividly discussed also for dementia associated with parkinsonian syndromes. This review focuses on the specific symptoms of dementia in different parkinsonian syndromes and critically questions the effect of cholinergic treatment on cognitive functions in patients with extrapyramidal syndromes and dementia. There is evidence that medication with some cholinesterase inhibitors can enhance cognition as well as activities of daily living in dementia with Parkinson's disease and seems to reduce behavioural disturbances in both dementia with Parkinson's disease and dementia with Lewy bodies. The effect of treatment with cholinesterase inhibitors in progressive supranuclear palsy and
\end{abstract}

corticobasal degeneration warrants carefully designed studies including a sufficient number of patients and symptomadopted dementia scales.

Copyright $\odot 2007$ S. Karger AG, Basel

\section{Introduction}

Behavioural symptoms and dementia are important predictors for nursing home placement and mortality in patients with parkinsonian syndromes $[1,2]$ and are an important component for the reduction of a patient's quality of life [3]. As a major source of distress both to patients and their families they can be more debilitating than the motor symptoms. Therefore, useful therapeutic strategies and effective management of these deficits is essential. Dementias associated with varying neurodegenerative processes comprise the largest group of dementive diseases, the most frequent diagnosis being Alzheimer disease (AD) at about $60 \%$ [4]. The second most common group of the neurodegenerative dementias are those associated with parkinsonian syndromes [5], including idiopathic Parkinson's disease (PD), dementia with Lewy bodies (DLB), progressive supranuclear palsy (PSP) and corticobasal degeneration (CBD). In contrast, the atypical parkinsonian syndrome multiple system atrophy is not usually associated with cognitive deteriora- 
tion [6]. Some forms of spinocerebellar atrophies [7], the Westphal variant of Huntington's disease [8] and the fragile X tremor ataxia syndrome [9] are other neurodegenerative disorders associated with both extrapyramidal parkinsonian syndromes and dementia [10]. In these disorders, additional neurological features predominate the clinical presentation. Therefore, the focus of the following review will be on dementia associated with $\mathrm{PD}$, DLB, PSP and CBD.

Dementia in parkinsonism is often referred to as a subcortical dementia [11]. In contrast to degenerative disorders with primary cortical involvement such as $\mathrm{AD}$, higher cortical dysfunctions (e.g. aphasia or apraxia) are not an initial component of the disease process; they occur to a lesser extent at later stages. The aetiology of dementia in patients with extrapyramidal motor symptoms is still under investigation. Lewy body (LB) pathology is correlated with the development and severity of dementia in patients with PD and DLB $[12,13]$, even though additional Alzheimer pathologies can be found [14]. Thus, there is increasing evidence that the occurrence and severity of dementia is primarily related to cortical changes rather than to alterations of subcortical structures [15], therefore, the term subcortical dementia is not appropriate for these disease entities.

Neuropathological and imaging studies in patients with DLB and Parkinson's disease with dementia (PDD) have shown that a number of neurotransmitter systems are affected in the dementive process, including the cholinergic, the noradrenergic and the serotonergic systems [16-18]. In PD, dopaminergic therapy is a favourable therapy for movement symptoms but has limited effects on cognitive functions [19]. The disruption of frontostriatal circuits due to corrupted dopaminergic neurons may cause deficits in executive functions. This dopaminergic contribution may account for an improvement in attentional and frontal functions in patients with PD without dementia by dopaminergic medication [20]. Outside of the dopaminergic system, a cholinergic deficit is the most impressive finding in PDD and the most consistent correlate $[16,21]$. In this context, the American Academy of Neurology recently made a recommendation for the use of the cholinesterase inhibitors (ChEIs) rivastigmine and donepezil in the treatment of PDD [22]. Moreover, a cholinergic deficit is also associated with memory decline in DLB [23]. Reduction in choline acetyltransferase activity has not only been found in the basal forebrain in AD but also in DLB, notably in the nucleus basalis of Meynert [16]. In PSP, selectivity for cholinergic lesions led to the suggestion that cholinergic stimulation is a favourable medicinal option. Several cholinergic regions, basal forebrain, basal ganglia, and mediodorsal thalamic nuclei, are affected, while the cortical neurons and other neurotransmitter systems are relatively spared [24]. Muscarinic blockade with low doses of scopolamine worsens memory and gait function in PSP patients [25]. Furthermore, acetylcholinesterase activity measured in lumbar cerebrospinal fluid of patients with PSP is significantly reduced by $31 \%$ relative to healthy controls [26]. Reduction of cholinergic activity is also reported in patients with CBD [27].

This review on the one hand summarizes the specific symptoms of dementia in different parkinsonian syndromes. On the other hand, it critically questions as well as compares the effect of cholinergic treatment on cognitive functions in each patient group. Initial studies indicate that treatment with ChEIs might be more beneficial for patients with PDD and DLB than for patients with AD [28-30]. The results among the studies investigating the effect of cholinergic treatment in patients with PDD are controversial and inconsistent across the individual syndromes.

\section{Methods}

To find relevant studies for treatment with ChEIs in patients with PDD, DLB, PSP and CBD, a search in Medline/PubMed and the Cochrane Database was performed (key words: Parkinson's dementia or dementia with Lewy bodies or corticobasal degeneration or progressive supranuclear palsy combined with each of the terms ChEI, rivastigmine, donepezil, tacrine, galantamine and physostigmine). Previous reviews [31-36] also served as basis for literature search.

\section{Inclusion/Exclusion Criteria}

Studies restricted to PDD, DLB, PSP and CBD in human subjects up to February 2006, which used at least 1 of the following ChEIs, were reviewed: rivastigmine, donepezil, tacrine, galantamine or physostigmine. Randomized controlled trials, non-randomized controlled trials and open-label studies were included. Only articles focusing primarily on treatment effects on cognition in demented patients were chosen and the presentation of the results had to be either based on a standardized scale, which measures global cognitive decline, or had to include at least the testing of memory function. Therefore, 3 articles were excluded from the review process [37-39]. In addition, studies which either focused only on subgroups of study samples for data analysis [40], or did not report numerous results of cognitive scales [41], or applied the drug only once [25] were excluded from further analysis.

Classification of Evidence

Each article was assigned by 1 reviewer (I.L.) to an a priori defined class of evidence (table 1) adapted from criteria proposed by the American Academy of Neurology. Recommendation for a 
therapeutic 'effective' intervention was made if at least 2 consistent class I studies in a representative population reported positive treatment effects. Rating as 'probably effective' required at least 1 representative class I or 2 positive class II studies. Use of ChEIs was defined as 'possibly effective' if 2 consistent studies in a representative population with evidence level III were reported or 1 class II study.

\section{Data Extraction}

For comparison of study outcome, the focus was on the frequently used Alzheimer's Disease Assessment Scale, cognition subscale (ADAScog), and the Mini-Mental State Examination (MMSE) or, if these scales were not used, on other standardized scales for the measurement of global cognitive decline or memory function (e.g. Mattis Dementia Rating Scale). Besides treatment effects on cognition, a worsening of parkinsonian syndromes, the occurrence of other side effects, changes of neuropsychiatric aspects and improvement of activities of daily living (ADL) were looked for. Studies interpreting different aspects of the same study population mentioned beforehand were reported but only counted once for therapeutic recommendation.

\section{Parkinson's Disease with Dementia}

Patients with PD have a 5- to 6-fold higher risk for developing dementia than age-matched control subjects without PD [42, 43]. Possible risk factors for PDD are older age, severe motor signs, depression, less L-dopa responsiveness and the occurrence of hallucinations in the disease course $[44,45]$.

Cognitive deficits are often associated with PD, although these deficits may be relatively subtle and not clinically apparent. Patients with PD without dementia have poor performance in frontal sensitive tasks including verbal fluency, problem solving and set shifting [46, 47]. Especially attentional deficits and disturbances in visuopraxis tests are among the first cognitive domains to show deterioration in PD. Impairment in memory tests affects mainly the retrieval of learned information [4850]. In PDD, these deficits are much more pronounced and influence the ADL [51].

The neurobiological mechanisms of dementia in $\mathrm{PD}$ are still under discussion. It has been questioned whether $\mathrm{LB}$ or $\mathrm{AD}$ pathology is the primary contributor to $\mathrm{PDD}$ [52]. Recent studies imply that neurodegeneration in PD ascends from the brainstem to the cerebral cortex [53]. This observation of a pathogenic process comprising the whole brain gives valuable information about the development of non-motor symptoms. Furthermore, an individual patient's neuropathological stage of $\mathrm{PD}$ has been suggested to be associated with their cognitive status [54]. The annual rate of brain atrophy has been corre-
Table 1. Classification of evidence

I Prospective randomized controlled trial with:

a Clear and defined primary outcome

b Clearly stated inclusion/exclusion criteria

c Adequate accounting for dropouts and crossovers with numbers sufficiently low

d Presentation of relevant baseline characteristics equivalent among different treatment groups or appropriate statistical adjustment for difference/reported appropriate baseline characteristics for each condition in crossover designs

II Prospective matched group cohort study with blinded outcome that meets all formerly mentioned quality criteria (see a-d above) or a randomized controlled trial in a representative population that lacks one of these criteria

III Controlled trial, where outcome is independently assessed

IV Evidence from uncontrolled studies

lated to global cognitive decline in patients with PD [55], whereas structural cortical changes may be heterogeneous in PDD [56-58]. In addition, PET data showed that cholinergic dysfunction was much stronger in PDD than in non-demented PD [17], and is correlated with performance in tests of working memory and attention [59]. These results support the assumption that treatment with ChEIs might be beneficial for patients with PDD.

\section{Treatment with ChEls in Patients with PDD}

\section{Number of Studies and Patients Enrolled according to} the Evidence Classification

We reviewed 3 studies with level I of evidence [60-62], 1 randomized double-blind study [63] classified as level III of evidence (explanation see below), 1 controlled trial [64] and 7 open-label studies [65-71] which examine the effect of ChEIs on cognition in PDD (tables 2, 3). Except for 3 studies $[63,68,69]$, the criteria for study inclusion were in accordance with the Diagnostic and Statistical Manual of Mental Disorders, 4th edition (DSM-IV) criteria. PD was mostly diagnosed according to the UK Brain Bank criteria $[60,63-67,69,70]$ or established depending on the appearance of clinical core symptoms of PD $[61,62,68]$.

\section{Effect of Treatment with ChEIs in PDD}

Information of stable coexisting dopaminergic medication was given in 1 class I study using rivastigmine [60] 
Table 2. Studies investigating the effect of cholinesterase inhibitors on cognitive deficits in PDD

\begin{tabular}{|c|c|c|c|c|c|c|c|c|c|}
\hline \multirow[t]{2}{*}{ Authors } & \multirow{2}{*}{$\begin{array}{l}\text { Level of } \\
\text { evidence }\end{array}$} & \multirow[t]{2}{*}{ Drug } & \multicolumn{3}{|l|}{ Patients } & \multirow{2}{*}{$\begin{array}{l}\text { Drop- } \\
\text { out, } \%\end{array}$} & \multicolumn{2}{|c|}{ Procedure and duration } & \multirow{2}{*}{$\begin{array}{l}\text { Mean dose } \\
\text { mg/day }\end{array}$} \\
\hline & & & $\mathrm{n}$ & & mean age, years & & & & \\
\hline Emre et al. [60], 2004 & $\mathrm{I}$ & rivastigmine & $\begin{array}{l}\text { dr. } \\
\text { plac. }\end{array}$ & $\begin{array}{l}362 \\
179\end{array}$ & $\begin{array}{l}73 \\
72\end{array}$ & $\begin{array}{l}27 \\
18\end{array}$ & treatment: & 24 weeks & 8.6 \\
\hline $\begin{array}{l}\text { Poewe et al. [66], } 2005 \\
\text { (further analysis of } \\
\text { study population by } \\
\text { Emre et al. [60], 2004) }\end{array}$ & (IV) & rivastigmine & $\begin{array}{l}\text { RCT } \\
\mathrm{OL}\end{array}$ & $\begin{array}{l}\text { (see above) } \\
334\end{array}$ & 72 & 18 & $\begin{array}{l}\text { RCT: } \\
\text { OL: }\end{array}$ & $\begin{array}{l}\text { (see above) } \\
24 \text { weeks }\end{array}$ & 7.9 \\
\hline Giladi et al. [67], 2003 & IV & rivastigmine & & 28 & 75 & 29 & $\begin{array}{l}\text { treatment: } \\
\text { washout: } \\
\text { withdrawal: }\end{array}$ & $\begin{array}{r}26 \text { weeks } \\
2 \text { weeks } \\
6 \text { weeks }\end{array}$ & 7.5 \\
\hline Reading et al. [70], 2001 & IV & rivastigmine & & 15 & 71 & 20 & $\begin{array}{l}\text { baseline: } \\
\text { treatment: } \\
\text { withdrawal: }\end{array}$ & $\begin{array}{r}10 \text { weeks } \\
14 \text { weeks } \\
3 \text { weeks }\end{array}$ & 8.0 \\
\hline Ravina et al. [62], 2005 & I & donepezil & $\begin{array}{l}\text { dr./plac. } \\
\text { plac./dr. }\end{array}$ & $\begin{array}{l}11 \\
11\end{array}$ & $\begin{array}{l}75 \\
72\end{array}$ & $\begin{array}{l}8 \\
9\end{array}$ & $\begin{array}{l}\text { treatment: } \\
\text { washout: } \\
\text { crossover design }\end{array}$ & $\begin{array}{l}2 \times 10 \text { weeks } \\
6 \text { weeks }\end{array}$ & 10 \\
\hline Aarsland et al. [61], 2002 & $\mathrm{I}$ & donepezil & $\begin{array}{l}\text { dr./plac. } \\
\text { plac./dr. }\end{array}$ & $\begin{array}{l}8 \\
6\end{array}$ & 71 & $\begin{array}{r}25 \\
0\end{array}$ & $\begin{array}{l}\text { treatment: } \\
\text { crossover design }\end{array}$ & $2 \times 10$ weeks & 9.6 \\
\hline Leroi et al. [63], 2004 & III & donepezil & $\begin{array}{l}\text { dr. } \\
\text { plac. }\end{array}$ & $\begin{array}{l}7 \\
9\end{array}$ & $\begin{array}{l}71 \\
66\end{array}$ & $\begin{array}{l}57 \\
22\end{array}$ & $\begin{array}{l}\text { treatment: } \\
\text { withdrawal: }\end{array}$ & $\begin{array}{l}18 \text { weeks } \\
12 \text { weeks }\end{array}$ & 6.4 \\
\hline Thomas et al. [64], 2005 & III & donepezil & $\begin{array}{l}\text { DLB } \\
\text { PDD }\end{array}$ & $\begin{array}{l}30 \\
40\end{array}$ & $\begin{array}{l}75 \\
71\end{array}$ & $\begin{array}{r}0 \\
15\end{array}$ & treatment: & 20 weeks & 9.5 \\
\hline Minett et al. [69], 2003 & IV & donepezil & $\begin{array}{l}\text { PDD } \\
\text { DLB }\end{array}$ & $\begin{array}{r}15 \\
9\end{array}$ & not stated & $\begin{array}{l}27 \\
11\end{array}$ & $\begin{array}{l}\text { treatment: } \\
\text { withdrawal: } \\
\text { recommencement }\end{array}$ & $\begin{array}{l}20 \text { weeks } \\
6 \text { weeks } \\
\text { : } 3 \text { months }\end{array}$ & $\begin{array}{l}\text { not stated } \\
5-10\end{array}$ \\
\hline Werber et al. [71], 2001 & IV & $\begin{array}{l}\text { donepezil/ } \\
\text { tacrine }\end{array}$ & $\begin{array}{l}\text { donepezil } \\
\text { tacrine }\end{array}$ & $\begin{array}{l}4 \\
7\end{array}$ & 75 & $\begin{array}{l}0 \\
0\end{array}$ & treatment: & 26 weeks & $\begin{array}{l}\text { donepezil: } 6.5 \\
\text { tacrine: } 100\end{array}$ \\
\hline $\begin{array}{l}\text { Hutchinson and } \\
\text { Fazzini [68], } 1996\end{array}$ & IV & tacrine & & 7 & 74 & 0 & treatment: & 2 months & 60 \\
\hline Aarsland et al. [65], 2003 & IV & galantamine & & 16 & 76 & 19 & treatment: & 8 weeks & 8 \\
\hline
\end{tabular}

dr. $=$ Drug; plac. $=$ placebo RCT $=$ randomized controlled trial; $\mathrm{OL}=$ open-label study

and 2 trials with donepezil $[61,63]$. Therefore, the effect of cholinergic treatment in these trials cannot be attributed to changes in antiparkinson medications in these trials. Medication affecting the cholinergic system [60$62,64,65,67,69,70]$ or drugs which influence cognition $[60,65,68,69]$ were mostly withdrawn before the treatment phase.

The treatment effect on cognition in randomized controlled trials was beneficial but small. Emre et al. [60] investigated a large sample $(n=541)$ and found a significant increase of approximately 1 point on the MMSE as well as 2 points on the ADAScog after 24 weeks of medication with rivastigmine. Furthermore, a significant im- provement in ADL scales, the global clinical impression score and in the global score of the neuropsychiatric inventory (NPI) was measured under drug condition. Patients in the placebo group (15.6\%) reported less frequent worsening of parkinsonism (mainly tremor) than patients treated with rivastigmine (27.3\%), whereas no significant difference was measured by the Unified Parkinson's Disease Rating Scale (UPDRS). With rivastigmine, side effects, e.g. nausea, vomiting and dizziness, were more frequently reported than with placebo medication; the amount of serious adverse events was similar in both groups (13.0 placebo vs. 14.5 rivastigmine). A secondary study of Emre et al. [60] in 334 participants with open- 
Table 3. Treatment effect of ChEIs on cognition and parkinsonian symptoms in PDD

\begin{tabular}{|c|c|c|c|c|c|c|c|}
\hline \multirow[t]{2}{*}{ Authors } & \multicolumn{4}{|c|}{ Mean cognition $\pm \mathrm{SD}$ at } & \multirow{2}{*}{$\begin{array}{l}\text { Sig- } \\
\text { nifi- } \\
\text { cance }\end{array}$} & \multirow{2}{*}{$\begin{array}{l}\text { Effect on parkinsonian } \\
\text { symptoms }\end{array}$} & \multirow[t]{2}{*}{ Other side effects } \\
\hline & baseline & & $\begin{array}{l}\text { follow-up after tr } \\
\text { phase }\end{array}$ & ceatment & & & \\
\hline $\begin{array}{l}\text { Emre et al. } \\
{[60], 2004}\end{array}$ & $\begin{array}{l}\text { ADAScog } \\
\text { drug } \\
\text { placebo } \\
M M S E \\
\text { drug } \\
\text { placebo }\end{array}$ & $\begin{array}{l}23.8 \pm 10.2 \\
24.3 \pm 10.5 \\
19.5 \pm 3.8 \\
19.2 \pm 4.0\end{array}$ & $\begin{array}{l}\text { ADAScog } \\
\text { drug } \\
\text { placebo } \\
\text { MMSE } \\
\text { drug } \\
\text { placebo }\end{array}$ & $\begin{array}{l}21.7 \pm 8.2 \\
25.0 \pm 7.5 \\
20.3 \pm 3.8 \\
19.0 \pm 3.5\end{array}$ & $\begin{array}{l}* * * \\
\text { n.s. } \\
*\end{array}$ & $\begin{array}{l}\text { frequency of worsening of } \\
\text { symptoms } \\
\text { drug } \quad 27.3 \% \\
\text { placebo } \quad 15.6 \% \\
\text { (tremor and } \\
\text { other symptoms) } \\
\text { no change in UPDRS }\end{array}$ & $\begin{array}{l}\text { frequency of adverse events } \\
\text { drug } \\
\text { placebo } \\
\text { (nausea, vomiting, dizziness, hallucina- } \\
\text { tions, orthostatic hypotension, etc.) }\end{array}$ \\
\hline $\begin{array}{l}\text { Poewe } \\
\text { et al. } \\
{[66], 2005}\end{array}$ & $\begin{array}{l}\text { ADAScog } \\
\text { drug } \\
\text { placebo } \\
\text { MMSE } \\
\text { drug } \\
\text { placebo }\end{array}$ & $\begin{array}{l}23.8 \pm 10.2 \\
24.3 \pm 10.5 \\
19.5 \pm 3.8 \\
19.2 \pm 4.0\end{array}$ & $\begin{array}{l}\text { ADAScog differen } \\
\text { drug/OL } \\
\text { placebo/OL } \\
\text { MMSE difference } \\
\text { drug/OL } \\
\text { placebo/OL }\end{array}$ & $\begin{array}{l}\text { nces } \\
2.0 \pm 7.3 \\
2.2 \pm 8.2 \\
1.2 \pm 4.0 \\
1.7 \pm 3.5\end{array}$ & n.t. & $\begin{array}{l}\text { frequency of worsening of } \\
\text { symptoms } \\
\text { OL } 18.0 \% \\
\text { (slight changes in UPDRS) }\end{array}$ & $\begin{array}{l}\text { frequency of adverse events } \\
\text { OL } \\
\text { (nausea, vomitting, tremor, falls, } \\
\text { confusional state, hallucinations, etc.) }\end{array}$ \\
\hline $\begin{array}{l}\text { Giladi et al. } \\
{[67], 2003}\end{array}$ & $\begin{array}{l}\text { ADAScog } \\
\text { MMSE }\end{array}$ & $\begin{array}{l}30.8 \pm 12.8 \\
20.5 \pm 5.1\end{array}$ & $\begin{array}{l}\text { ADAScog } \\
\text { MMSE }\end{array}$ & $\begin{array}{l}23.5 \pm 15.0 \\
21.9 \pm 5.4\end{array}$ & $\begin{array}{l}* * \\
\text { n.s. }\end{array}$ & $\begin{array}{l}\text { frequency of worsening of } \\
\text { symptoms } \\
\text { tremor } \\
\end{array}$ & $\begin{array}{l}\text { frequency of symptoms } \\
60.7 \% \text { more than } 1 \text { sign (salivation, } \\
\text { confusion, nausea, generalized weakness, } \\
\text { hyperhydrosis, diarrhea, etc.) }\end{array}$ \\
\hline $\begin{array}{l}\text { Reading et al. } \\
{[71], 2001}\end{array}$ & MMSE & $20.8 \pm 5.4$ & MMSE & $25.4 \pm 3.5$ & ** & no change in UPDRS & not stated \\
\hline $\begin{array}{l}\text { Ravina et al. } \\
{[62], 2005}\end{array}$ & & & $\begin{array}{l}\text { ADAScog } \\
\text { drug } \\
\text { placebo } \\
\text { treatment effect } \\
M M S E \\
\text { drug } \\
\text { placebo } \\
\text { treatment effect }\end{array}$ & $\begin{array}{l}22.5 \pm 6.9 \\
24.4 \pm 9.4 \\
-1.9 \\
24.5 \pm 3.2 \\
22.5 \pm 4.7 \\
2.0\end{array}$ & n.s. & no change in UPDRS & $\begin{array}{l}\text { frequency of adverse events } \\
\text { drug } \\
\text { placebo } \\
\text { (psychosis, agitation, nausea, etc.) }\end{array}$ \\
\hline $\begin{array}{l}\text { Aarsland } \\
\text { et al. } \\
{[61], 2002}\end{array}$ & & & $\begin{array}{l}\text { MMSE } \\
\text { drug } \\
\text { placebo }\end{array}$ & $\begin{array}{l}22.8 \pm 3.7 \\
21.0 \pm 5.0\end{array}$ & * & no change in UPDRS & 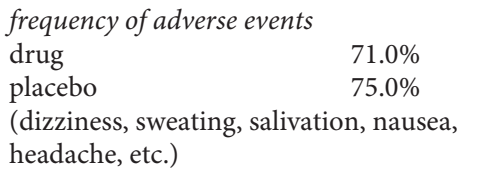 \\
\hline $\begin{array}{l}\text { Leroi } \\
\text { et al. } \\
{[63], 2004}\end{array}$ & $\begin{array}{l}M M S E \\
\text { drug } \\
\text { placebo }\end{array}$ & $\begin{array}{l}26.0 \pm 2.4 \\
25.4 \pm 3.3\end{array}$ & $\begin{array}{l}M M S E \\
\text { drug } \\
\text { placebo }\end{array}$ & $\begin{array}{l}25.3 \pm 3.8 \\
25.6 \pm 3.8\end{array}$ & n.s. & no change in UPDRS & $\begin{array}{lr}\text { frequency of adverse events } & \\
\text { drug } & 71.4 \% \\
\text { placebo } & 44.4 \% \\
\text { (acute diplopia, lightheadedness, etc.) }\end{array}$ \\
\hline $\begin{array}{l}\text { Thomas } \\
\text { et al. } \\
\text { [64], } 2005\end{array}$ & $\begin{array}{l}\text { MMSE } \\
\text { DLB } \\
\text { PDD }\end{array}$ & $\begin{array}{l}17.7 \\
18.3\end{array}$ & $\begin{array}{l}\text { MMSE } \\
\text { DLB } \\
\text { PDD }\end{array}$ & $\begin{array}{l}21.6 \\
21.5\end{array}$ & n.s. & no change in UPDRS & $\begin{array}{l}\text { frequency of adverse events } \\
\text { hypersalivation } \\
\text { nausea/vomiting } \\
\text { urinary frequency } \\
\text { more lachrymal secretion }\end{array}$ \\
\hline $\begin{array}{l}\text { Minett } \\
\text { et al. } \\
\text { [69], } 2003\end{array}$ & $\begin{array}{l}M M S E \\
\text { PDD } \\
\text { DLB }\end{array}$ & $\begin{array}{l}17.5 \\
15.8\end{array}$ & $\begin{array}{l}\text { MMSE } \\
\text { PDD } \\
\text { DLB }\end{array}$ & $\begin{array}{l}21.3 \\
19.9\end{array}$ & ** & no change in UPDRS & $\begin{array}{l}\text { frequency of adverse events } \\
\text { nausea } \\
\text { hypersalivation } \\
\text { tremor } \\
\text { cramps }\end{array}$ \\
\hline $\begin{array}{l}\text { Werber } \\
\text { et al. } \\
\text { [71], } 2001\end{array}$ & $\begin{array}{l}\text { ADAScog } \\
\text { MMSE }\end{array}$ & $\begin{array}{l}32.6 \pm 14.3 \\
18.6 \pm 2.7\end{array}$ & $\begin{array}{l}\text { ADAScog } \\
\text { MMSE }\end{array}$ & $\begin{array}{l}29.4 \pm 6.0 \\
19.9 \pm 3.3\end{array}$ & $\begin{array}{l}* \\
\text { n.s. }\end{array}$ & no change in SPES & (nausea, anorexia and dizziness) \\
\hline
\end{tabular}


Table 3 (continued)

\begin{tabular}{|c|c|c|c|c|c|c|c|c|c|}
\hline \multirow[t]{2}{*}{ Authors } & \multicolumn{4}{|c|}{ Mean cognition $\pm \mathrm{SD}$ at } & \multirow{2}{*}{$\begin{array}{l}\text { Sig- } \\
\text { nifi- } \\
\text { cance }\end{array}$} & \multirow{2}{*}{\multicolumn{2}{|c|}{$\begin{array}{l}\text { Effect on parkinsonian } \\
\text { symptoms }\end{array}$}} & \multirow{2}{*}{\multicolumn{2}{|c|}{ Other side effects }} \\
\hline & \multicolumn{2}{|l|}{ baseline } & \multicolumn{2}{|c|}{$\begin{array}{l}\text { follow-up after treatment } \\
\text { phase }\end{array}$} & & & & & \\
\hline $\begin{array}{l}\text { Hutchinson } \\
\text { and Fazzini } \\
{[68], 1996}\end{array}$ & MMSE & $16.6 \pm 2.4$ & MMSE & $23.7 \pm 1.5$ & $* * *$ & $\begin{array}{l}\text { improvement } \mathrm{i} \\
\text { no change in } \mathrm{m}\end{array}$ & $\begin{array}{l}\text { UPDRS, } \\
\text { tor scores }\end{array}$ & not stated & \\
\hline $\begin{array}{l}\text { Aarsland } \\
\text { et al. } \\
{[65], 2003}\end{array}$ & MMSE & $18.5 \pm 7.1$ & MMSE & $20.8 \pm 5.4$ & n.s. & $\begin{array}{l}\text { improvement } \\
\text { no change } \\
\text { deterioration }\end{array}$ & $\begin{array}{l}46.2 \% \\
30.8 \% \\
23.1 \%\end{array}$ & $\begin{array}{l}\text { frequency of adverse events } \\
\text { (vomiting, tremor, anorexia, } \\
\text { nausea, gastrointestinal side } \\
\text { effects, sedation, headache) }\end{array}$ & $73.5 \%$ \\
\hline
\end{tabular}

$\mathrm{OL}=$ Open-label study; SPES = Short Parkinson Evaluation Scale; n.t. = not statistically tested; $\mathrm{n} . \mathrm{s}$. = test difference statistically not significant; ${ }^{*} \mathrm{p}<0.05,{ }^{* *} \mathrm{p}<0.01,{ }^{* * *} \mathrm{p}<0.001$.

label treatment of rivastigmine for 24 weeks showed nearly comparable test performance to baseline testing after 1 year, which was not statistically pointed out [66].

Efficacy of treatment with donepezil was explored in 3 double-blind randomized controlled trials. Ravina et al. [62] examined 22 patients treated 10 weeks with each donepezil and placebo in a randomized order. Improvement in the MMSE (2 points) and of global clinical impression, but not in the ADAScog and in the behavioural scales, was addressed after application of a daily dose of $10 \mathrm{mg}$ donepezil. The frequency of adverse side events of treatment (52\%) and placebo (45\%) phases did not differ and worsening of parkinsonian syndrome did not occur. Another class I study with donepezil [61] but a low patient number also supports this beneficial effect on cognition. Reduction of psychiatric symptoms was not found. Seventy-one percent of patients reported some adverse side effect with placebo treatment and $75 \%$ with the verum, with no statistical difference between the groups. Still there was a tendency that patients reported more specific adverse events like nausea, headache and salivation under the drug condition. In contrast to these consistent outcomes of class I studies, Leroi et al. [63] did not support these positive results under donepezil treatment, which is probably a cause of inconsistent criteria for the diagnosis of dementia and low patient numbers included. In addition, there may also be the possibility of testing bias due to a high rate (57\%) of dropouts under drug medication [63]. Open-label studies on average achieved greater differences between medication and placebo in test scores but still have the problem of an uncontrolled placebo effect and testing bias.
There is evidence that medication with the ChEIs rivastigmine or donepezil is moderately effective to enhance cognitive function in PDD. In addition, rivastigmine seems to be probably effective in the treatment of behavioural disturbances and ADL function, but further proof of these aspects is needed $[60,66]$. As the sample sizes in the studies using donepezil were small, varying between 14 and 22 patients, the results need to be verified in future studies. However, the crossover design used in the donepezil trials requires fewer subjects than the parallel group structure [72]. Adverse side effects did not primarily worsen parkinsonian syndromes but affected mainly the gastrointestinal system (e.g. nausea, vomiting). Taken together, there is a tendency to a higher dropout rate under medication relative to placebo in 1 trial using rivastigmine [60] and 1 study with donepezil [63]. Presently, there are no controlled studies using the ChEIs galantamine and tacrine so that the effectiveness of these ChEIs cannot be evaluated. The first results of open-label trials indicate that beneficial treatment effects with galantamine and tacrine could be supposed.

\section{Dementia with Lewy Bodies}

The central clinical features required for the diagnosis of DLB are progressive cognitive decline that interferes with normal social and occupational function, fluctuation in cognition, recurrent visual hallucinations and/or parkinsonian motor disabilities. The phenomenon of fluctuations in DLB includes both sleepiness and altered arousal. The rapid eye movement sleep behaviour disorder is present in nearly half of the DLB patients and 
often a preclinical sign of the disease [73]. Other supportive diagnostic features are repeated falls, syncopes, neuroleptic sensitivity, hallucinations in other modalities and depression [74]. As the criteria for DLB are highly specific but the sensitivity of the diagnosis seems to be low [75], the guidelines for the diagnosis of DLB were recently modified [76]. The most common misdiagnosis of DLB is AD [77]. Furthermore, PDD and DLB are 2 syndromes with overlapping clinical symptoms and both diseases are neuropathologially characterized by LB disease [78]. In contrast, additional AD pathology is much more frequent in DLB than in PDD, and LBs are more pronounced in the temporal cortex in DLB $[12,79]$. The clinical discrimination to PDD has been set by convention using the time criteria of occurrence of motor symptoms [76].

Cognitive functions of DLB patients are impaired in all areas of cognition and show high variability [80, 81]. Prominent memory impairment may not necessarily occur in the early stages. Rather performance in attentional and visuospatial tasks as well as tests of executive functions are disturbed [82-84]. Nevertheless, memory impairment is usually evident with progression of the disease. Although there are some hints that the neuropsychological test profile may differ between DLB and AD $[76,83]$, DLB can be suspected but not diagnosed with certainty on the basis of a cognitive profile alone.

Limbic and cortical LB are associated with cognitive decline, both in DLB and PDD [85]. Additionally, it has frequently been demonstrated $[86,87]$ that in many cases the pathology of DLB involves a combination of LB and $\mathrm{AD}$ pathological features ( $\beta$-amyloid depositions and diffuse plaque formation).

Compared to $\mathrm{AD}$, hippocampal and medial temporal lobe atrophy are less pronounced in DLB [88]. However, the global rate of brain atrophy is similar in patients with DLB and patients with other aetiologies of dementia [89]. Patients with DLB suffer from perfusion deficits in the parietal and frontal regions of the brain [90], as do patients with $\mathrm{AD}$ [91]. In contrast to $\mathrm{AD}$, occipital hypoperfusion and hypometabolism are found in patients with DLB [92-95]. As we know from DaT-SCAN SPECT, the nigrostriatal dopaminergic function is more severely impaired in patients with DLB compared to patients with $\mathrm{AD}$ [96] but does not differ from patients with PD [97].

DLB patients have a pronounced dysfunction of the cholinergic neurotransmitter system which is even greater than that seen in patients with $\mathrm{AD}[16,98]$. Cholinergic activity is lower in DLB patients with compared to those without hallucinations, which suggests that also halluci- nations might be reduced after therapeutic intervention with cholinergic agents [99-101]. Management of DLB includes an accurate diagnosis, identification of target syndrome, as well as non-pharmacological and pharmacological intervention [102].

\section{Treatment with ChEls in Patients with DLB}

Number of Studies and Patients Enrolled according to the Evidence Classification

We found 1 study that fulfilled the criteria of evidence class I [103], 1 class III study [104], 3 open-label trials that statistically compared the test performance of different patient groups $[30,64,105]$ and $3[106,107]$ open-label studies (table 4). Wesnes et al. [108] published a supplementary analysis of the trial of McKeith et al. [103], and 2 open-label follow-up examinations $[109,110]$ included patients of this large study sample. In all trials, diagnosis was made in accordance with the consensus guidelines of the consortium on DLB obtained at an international workshop [111]. Neuroleptics and anticholinergic agents before or during the treatment phase were not allowed in 5 studies $[69,103,105,108,109]$, while psychotropics were allowed to be continued in 2 trials $[30,64]$.

\section{Treatment with ChEIs in DLB}

McKeith et al. [103] carried out a randomized doubleblind multicenter study with a representative sample size $(n=120)$. Although the slight improvement in the MMSE score of patients treated with rivastigmine compared to the placebo group did not reach significance (table 5), there was a significant reduction in some behavioural domains of the NPI, e.g. apathy, indifference, anxiety or delusions. Comparison of performance on a computerized cognitive assessment system (Cognitive Drug Research) revealed positive changes superior to baseline performance in tests of attention and memory after the drug phase, which decreased to baseline level shortly after withdrawal [108]. More patients on rivastigmine (55.0\%) than on placebo (46.8\%) had adverse events [103]. However, the frequency of severe adverse events was comparable between the drug and placebo groups. The side effects were predominantly gastrointestinal in nature (e.g. nausea, anorexia, diarrhoea). There was no change in comparison to baseline and placebo in the motor section of the UPDRS after intervention with rivastigmine, whereas patients with severe extrapyramidal symptoms were excluded from the trial due to the risk of worsening of parkinsonism. Performance in cognition after nearly 
Table 4. Studies which investigate the effect of ChEIs on cognitive deficits in DLB

\begin{tabular}{|c|c|c|c|c|c|c|c|c|c|}
\hline \multirow[t]{2}{*}{ Authors } & \multirow{2}{*}{$\begin{array}{l}\text { Level of } \\
\text { evidence }\end{array}$} & \multirow[t]{2}{*}{ Drug } & \multicolumn{3}{|l|}{ Patients } & \multirow{2}{*}{$\begin{array}{l}\text { Dropout } \\
\%\end{array}$} & \multirow{2}{*}{\multicolumn{2}{|c|}{ Procedure and duration }} & \multirow{2}{*}{$\begin{array}{l}\text { Mean dose } \\
\text { mg/day }\end{array}$} \\
\hline & & & $\mathrm{n}$ & & mean age, years & & & & \\
\hline $\begin{array}{l}\text { McKeith et al. } \\
{[103], 2000}\end{array}$ & $\mathrm{I}$ & rivastigmine & $\begin{array}{l}\text { drug } \\
\text { placebo }\end{array}$ & $\begin{array}{l}59 \\
61\end{array}$ & $\begin{array}{l}74 \\
74\end{array}$ & $\begin{array}{l}31 \\
16\end{array}$ & $\begin{array}{l}\text { treatment: } \\
\text { withdrawal: }\end{array}$ & $\begin{array}{r}20 \text { weeks } \\
3 \text { weeks }\end{array}$ & 9.4 \\
\hline $\begin{array}{l}\text { Wesnes et al. [108], } 2002 \text { (further } \\
\text { analysis of study population by } \\
\text { McKeith et al. [103], 2000) }\end{array}$ & (I) & rivastigmine & $\begin{array}{l}\text { drug } \\
\text { placebo }\end{array}$ & $\begin{array}{l}59 \\
61\end{array}$ & $\begin{array}{l}74 \\
74\end{array}$ & $\begin{array}{l}31 \\
16\end{array}$ & $\begin{array}{l}\text { treatment: } \\
\text { withdrawal: }\end{array}$ & $\begin{array}{r}20 \text { weeks } \\
3 \text { weeks }\end{array}$ & 9.4 \\
\hline $\begin{array}{l}\text { McKeith et al. [103], } 2000 \\
\text { (members of study population by } \\
\text { McKeith [103], 2000) }\end{array}$ & $(\mathrm{IV})$ & rivastigmine & & 11 & 79 & 0 & treatment: & 12 weeks & 9.6 \\
\hline $\begin{array}{l}\text { Grace et al. [110], } 2001 \\
\text { (members of study population by } \\
\text { McKeith et al. [103], 2000) }\end{array}$ & (IV) & rivastigmine & & 29 & 76 & 31 & treatment: & 96 weeks & $\begin{array}{l}\text { not stated } \\
3-12\end{array}$ \\
\hline Grace et al. [107], 2000 & IV & rivastigmine & & 6 & 75 & 0 & treatment: & 12 weeks & not stated \\
\hline Beversdorf et al. [104], 2004 & III & donepezil & & 7 & 65 & 14 & $\begin{array}{l}\text { treatment: } \\
\text { placebo: } \\
\text { crossover inter- } \\
\text { mixed design }\end{array}$ & $\begin{array}{l}2 \times 4 \text { weeks } \\
2 \times 4 \text { weeks }\end{array}$ & 5 \\
\hline Thomas et al. [64], 2005 & III & donepezil & $\begin{array}{l}\text { DLB } \\
\text { PDD }\end{array}$ & $\begin{array}{l}30 \\
40\end{array}$ & $\begin{array}{l}75 \\
71\end{array}$ & $\begin{array}{r}0 \\
15 \\
\end{array}$ & treatment: & 20 weeks & 9.5 \\
\hline Samuel et al. [30], 2000 & III & donepezil & $\begin{array}{l}\mathrm{DLB} \\
\mathrm{AD}\end{array}$ & $\begin{array}{r}4 \\
12 \\
\end{array}$ & $\begin{array}{l}80 \\
76\end{array}$ & $\begin{array}{l}0 \\
0\end{array}$ & treatment: & 6 months & 5 \\
\hline Minett et al. [69], 2003 & IV & donepezil & $\begin{array}{l}\text { PDD } \\
\text { DLB }\end{array}$ & $\begin{array}{r}15 \\
9\end{array}$ & not stated & $\begin{array}{l}27 \\
11\end{array}$ & $\begin{array}{l}\text { treatment: } \\
\text { withdrawal: } \\
\text { recommencement: }\end{array}$ & $\begin{array}{l}20 \text { weeks } \\
6 \text { weeks } \\
3 \text { months }\end{array}$ & $\begin{array}{l}\text { not stated } \\
5-10\end{array}$ \\
\hline Querfurth et al. [105], 2000 & III & tacrine & $\begin{array}{l}\mathrm{DLB} \\
\mathrm{AD}\end{array}$ & $\begin{array}{l}6 \\
6\end{array}$ & $\begin{array}{l}79 \\
75\end{array}$ & $\begin{array}{r}17 \\
0\end{array}$ & treatment: & 24 weeks & 80 \\
\hline Edwards et al. [106], 2004 & IV & galantamine & & 25 & 76 & 8 & treatment: & 12 weeks & $\begin{array}{l}\text { not stated } \\
8-24\end{array}$ \\
\hline
\end{tabular}

2 years of treatment with rivastigmine was not superior to baseline performance, although no significant deterioration within this time period occurred [110]. In addition, further open-label studies did not characterize improvement on cognitive functions due to rivastigmine in DLB patients [107, 109].

Beversdorf et al. [104] designed a double-blind, double-crossover study (class III, no exclusion criteria and baseline characteristics reported) with the ChEI donepezil in a small group of 7 patients. In spite of the short treatment phase (4 weeks), MMSE and ADAScog scores were significantly more improved after donepezil than after placebo medication, about 2 points each. Functional ability did not improve, neither did achievement of verbal fluency or visuospatial functions. Information concerning side effects was not given. Another class III study compared the performance of patients with PDD and DLB. The magnitude of improved global cognition and reduced behavioural disturbances did not differ in these disease entities [64]. However, the MMSE score increased by about 4 points after 20 weeks of treatment with donepezil. Samuel et al. [30] reported a 5-fold higher increase in the MMSE score in DLB compared to AD after a 6 months of application of donepezil. However, limitations of the study are the small number of patients with DLB ( $\mathrm{n}=4)$ and the additional vascular brain defects (lacunes) in 3 of 4 DLB patients. Minett et al. [69] conducted an open-label study and found a significant improvement in the MMSE score (+ 4.1 points). Overall changes of psychiatric symptoms (total NPI score) were not noted, but hallucination, depression and anxiety were affected by medication. Frequently reported adverse events were tremor, vomiting and hypersalivation. 
Table 5. Treatment effect of cholinesterase inhibitors on cognition and Parkinsonian symptoms in DLB

\begin{tabular}{|c|c|c|c|c|c|c|c|c|}
\hline \multirow[t]{2}{*}{ Authors } & \multicolumn{4}{|c|}{ Mean cognition $\pm S D$ at } & \multirow{2}{*}{$\begin{array}{l}\text { Signifi- } \\
\text { cance }\end{array}$} & \multirow{2}{*}{$\begin{array}{l}\text { Effect on parkinsonian } \\
\text { symptoms }\end{array}$} & \multirow{2}{*}{\multicolumn{2}{|c|}{ Other side effects }} \\
\hline & baseline & & $\begin{array}{l}\text { follow-up after } \\
\text { treatment phase }\end{array}$ & & & & & \\
\hline $\begin{array}{l}\text { McKeith et al. [103], } \\
2000\end{array}$ & $\begin{array}{l}\text { MMSE } \\
\text { drug } \\
\text { placebo }\end{array}$ & $\begin{array}{l}17.9 \pm 4.7 \\
17.8 \pm 4.4\end{array}$ & $\begin{array}{l}\text { MMSE } \\
\text { drug } \\
\text { placebo }\end{array}$ & $\begin{array}{l}18.4 \\
17.7\end{array}$ & n.s. & no change in UPDRS & $\begin{array}{l}\text { frequency of adverse e } \\
\text { drug } \\
\text { placebo } \\
\text { (nausea, vomiting, an } \\
\text { somnolence) }\end{array}$ & $\begin{array}{l}\text { vents } \\
54.9 \% \\
46.8 \% \\
\text { iorexia, }\end{array}$ \\
\hline $\begin{array}{l}\text { Wesnes et al. [108], } \\
2002 \text { (further analysis of } \\
\text { study population by } \\
\text { McKeith et al. [103], 2000) }\end{array}$ & $\begin{array}{l}\text { CDR: overo } \\
\text { memory } \\
\text { drug } \\
\text { placebo }\end{array}$ & $\begin{array}{l}\text { all quality of } \\
1.8 \\
1.8\end{array}$ & $\begin{array}{l}\text { CDR: Overall quali } \\
\text { memory } \\
\text { drug } \\
\text { placebo }\end{array}$ & $\begin{array}{l}\text { ity of } \\
1.9 \\
1.6\end{array}$ & * & not stated & not stated & \\
\hline $\begin{array}{l}\text { Mc Keith et al. [103], } \\
2000 \text { (members of study } \\
\text { population by McKeith } \\
\text { et al. [103], 2000) }\end{array}$ & MMSE & $18.9 \pm 5.1$ & MMSE & $19.6 \pm 5.1$ & n.s. & $\begin{array}{l}\text { reduction in UPDRS } \\
\text { score }\end{array}$ & $\begin{array}{l}\text { no severe adverse side } \\
\text { occurred } \\
\text { (nausea and diarrhoee }\end{array}$ & a) effects \\
\hline $\begin{array}{l}\text { Grace [110], } 2001 \\
\text { (members of study } \\
\text { population by McKeith } \\
\text { et al. [103], 2000) }\end{array}$ & MMSE & 19.2 & MMSE & 15.5 & n.s. & $\begin{array}{l}\text { no change in } \\
\text { UPDRS }\end{array}$ & not stated & \\
\hline $\begin{array}{l}\text { Grace et al. [107], } \\
2000\end{array}$ & MMSE & 18.5 & MMSE & 23.0 & n.t. & not stated & not stated & \\
\hline $\begin{array}{l}\text { Beversdorf et al. } \\
{[104], 2004}\end{array}$ & $\begin{array}{l}\text { ADAScog } \\
\text { MMSE }\end{array}$ & $\begin{array}{l}25.4 \pm 20.1 \\
18.7 \pm 10.7\end{array}$ & $\begin{array}{l}\text { ADAScog } \\
\text { drug } \\
\text { placebo } \\
M M S E \\
\text { drug } \\
\text { placebo }\end{array}$ & $\begin{array}{l}23.5 \pm 18.1 \\
27.2 \pm 19.2 \\
20.7 \pm 7.4 \\
19.0 \pm 8.6\end{array}$ & * & $\begin{array}{l}\text { no change in } \\
\text { UPDRS }\end{array}$ & not stated & \\
\hline $\begin{array}{l}\text { Thomas et al. [64], } \\
2005\end{array}$ & $\begin{array}{l}M M S E \\
\text { DLB } \\
\text { PDD }\end{array}$ & $\begin{array}{l}17.7 \\
18.3\end{array}$ & $\begin{array}{l}M M S E \\
\text { DLB } \\
\text { PDD }\end{array}$ & $\begin{array}{l}21.6 \\
21.5\end{array}$ & n.s. & no change in UPDRS & $\begin{array}{l}\text { frequency of adverse e } \\
\text { hypersalivation } \\
\text { nausea/vomiting } \\
\text { urinary frequency } \\
\text { more lachrymal } \\
\text { secretion }\end{array}$ & $\begin{array}{r}\text { vents } \\
24 \% \\
18 \% \\
15 \% \\
\\
15 \%\end{array}$ \\
\hline $\begin{array}{l}\text { Samuel et al. [30], } \\
2000\end{array}$ & $\begin{array}{l}\text { MMSE } \\
\text { DLB } \\
\text { AD }\end{array}$ & $\begin{array}{l}20.5 \pm 3.1 \\
19.6 \pm 4.1\end{array}$ & $\begin{array}{l}\text { MMSE } \\
\text { DLB } \\
\mathrm{AD}\end{array}$ & $\begin{array}{l}25.3 \\
20.1\end{array}$ & * & not stated & not stated & \\
\hline $\begin{array}{l}\text { Minett et al. [69], } \\
2003\end{array}$ & $\begin{array}{l}M M S E \\
\text { PDD } \\
\text { DLB }\end{array}$ & $\begin{array}{l}17.5 \\
15.8\end{array}$ & $\begin{array}{l}\text { MMSE } \\
\text { PDD } \\
\text { DLB }\end{array}$ & $\begin{array}{l}21.3 \\
19.9\end{array}$ & ** & no change in UPDRS & $\begin{array}{l}\text { frequency of adverse } \\
\text { nausea } \\
\text { hypersalivation } \\
\text { tremor } \\
\text { cramps, etc. }\end{array}$ & $\begin{array}{c}\text { events } \\
29 \% \\
29 \% \\
29 \% \\
25 \%\end{array}$ \\
\hline $\begin{array}{l}\text { Querfurth et al. [105], } \\
2000\end{array}$ & $\begin{array}{l}\text { DRS } \\
\mathrm{DLB} \\
\mathrm{AD}\end{array}$ & $\begin{array}{l}93.8 \pm 19.8 \\
113.7 \pm 8.7\end{array}$ & $\begin{array}{l}\text { DRS } \\
\text { DLB } \\
\text { AD }\end{array}$ & $\begin{array}{l}77.0 \pm 47.7 \\
106.3 \pm 9.9\end{array}$ & $\begin{array}{l}\text { n.s. } \\
\text { (n.s) } \\
(*)\end{array}$ & $\begin{array}{l}\text { worsening of } \\
\text { parkinsonism }\end{array}$ & not stated & \\
\hline $\begin{array}{l}\text { Edwards et al. [106], } \\
2004\end{array}$ & & & $\begin{array}{l}\text { ADAScog change } \\
\text { MMSE change }\end{array}$ & $\begin{array}{l}-2.8 \\
1.6\end{array}$ & $\begin{array}{l}\text { n.s. } \\
*\end{array}$ & no change in UPDRS & $\begin{array}{l}\text { frequency of adverse } \\
\text { events (nausea, } \\
\text { vertigo, anorexia, } \\
\text { dyspepsia, etc.) }\end{array}$ & $48.0 \%$ \\
\hline
\end{tabular}

DRS = Mattis Dementia Rating Scale; CDR = Cognitive Drug Research computerized attention battery; .s. = test difference statistically not significant; n.t. $=$ not statistically tested; ${ }^{*} \mathrm{p}<0.05,{ }^{* *} \mathrm{p}<0.01$. 
Querfurth et al. [105] did not confirm a superior treatment effect of tacrine in patients with DLB. However, 1 open-label study that investigated the treatment effect of galantamine [106] reported a significant improvement in the MMSE and in 4 subscales of the NPI (delusion, hallucination, apathy and depression) after 12 weeks of medication. Further controlled trials in a representative study sample for the evaluation of the treatment effect of tacrine and galantamine are needed.

First results in DLB show only slight improvement of cognitive dysfunction due to treatment with rivastigmine. However, ChEIs are probably effective in the reduction of behavioural disturbances. Only one third of all studies focused on safety analysis $[103,106,109]$. There, adverse side events tended to be more frequent in patients treated with rivastigmine than with placebo. In addition, treatment with ChEIs can cause hypersalivation, hypertension and falls in patients with DLB [102]. Worsening of parkinsonian symptoms did not occur after 20 weeks of blinded drug treatment $[103,104]$, which is supported by most of the open-label trials $[64,69,106,109,110]$.

\section{Progressive Supranuclear Palsy}

PSP is characterized by mostly asymmetrical parkinsonism, postural instability, supranuclear vertical gaze palsy, axial rigidity with abnormal posturing of the neck, frontal lobe syndrome and dementia [112, 113]. Personality changes occur frequently in the disease course, particularly apathy and disinhibition. Approximately 40$50 \%$ of the patients have signs of depression [114] and sleep disturbances [115]. Occurrence and severity of depression, however, seem to be independent of the cognitive state [116].

Cognition is not necessarily disturbed in PSP but dementia occurs in more than $50 \%$ of patients. Usually, executive functions are most severely affected $[117,118]$. Patients have slowed information processing and motor execution, affected long-term memory, limited attentional resources and difficulties in planning and problem solving as well as in set shifting $[115,119]$. Breakdown in verbal memory is less pronounced than in AD [120]. On the other hand, phonematic and semantic fluency are severely disturbed and more affected than in patients with PD or multiple system atrophy $[121,122]$. Although limb apraxia is an important diagnostic sign of CBD, it is also found in patients with PSP [123]. Apraxia is predominantly classified as ideomotor apraxia $[124,125]$ and associated with dementia [126].
PSP is a sporadic neurodegenerative disorder, neuropathologically defined as a tauopathy with prominent subcortical and cortical neurofibrillary degeneration [127]. The exact aetiology of tau pathology in PSP is unknown. First studies show pathologic tau composed of aggregated 4-repeat (E10+) tau isoforms that accumulate in neurons and glia in subcortical and cortical areas [128]. Cortical tau aggregation is mainly found in the motor and the frontal cortex [129-131]. The amount of frontal lobe atrophy and the existence of cortical tau pathology in PSP patients are suggested to be associated with behavioural changes and dementia [132-134]. However, subcortical changes are traditionally considered to play a decisive role in the development of cognitive loss in PSP [135].

\section{Treatment with ChEls in Patients with PSP}

PSP progresses inevitably and presently there is no effective therapy [136]. Cholinergic dysfunction is related to changes of cortical and subcortical neurotransmitter systems (for review see [34]). Therefore, it has been proposed that cholinergic treatment can be helpful for symptoms related to cholinergic dysfunction in PSP patients. However, there are also studies that failed to show any abnormalities in cholinergic cortical activity in contrast to PD $[137,138]$.

\section{Treatment with Physostigmine in PSP Patients}

Two double-blind, placebo-controlled crossover studies investigated the effect of physostigmine, a short-acting ChEI, on cognition in PSP. Due to lack of information concerning the methodological background, both articles have to be rated as class III studies. Litvan et al. [139] included 8 patients (median age: 64 years) who received 0.5-2.0 mg of physostigmine 6 times a day for 10 days. Diagnosis of dementia was based on the criteria of the revised third edition of the DSM. Improvement in longterm memory was assessed, but no change in the performance of short-term memory functions was noticed. Drug-induced improvement in cognition correlated with global motor impairment, which indicated that only the less impaired PSP patients respond to physostigmine stimulation. Worsening of motor performance or other side effects was not seen after treatment with physostigmine. Moreover, the levels of acetylcholine in the cerebrospinal fluid (CSF) did not change during drug administration. Blin et al. [140] examined the influence of physostigmine on neuropsychological test performance and 
on changes in FDG-PET in 6 PSP patients aged 68-74 years. Both physostigmine and placebo infusions were given for the duration of one week, each in randomized order. Some improvement was noted in tasks of attention and memory. Brain glucose metabolism was altered in every brain region because of drug application. The transfer of glucose from blood to brain was increased with physostigmine from $8 \%$ in the frontal cortex to $32 \%$ in the thalamus. Motor symptoms were not modified between drug and placebo phases. No severe adverse events were recorded.

\section{The Efficacy of Donepezil in PSP}

Two studies investigated treatment effects of longer acting ChEIs, both with the ChEI donepezil. One [141] double-blind placebo-controlled randomized crossover trial (level I of evidence) randomized 22 patients (mean age: 66 years). One patient dropped out before the treatment had started. The remaining 21 patients were treated for 6 weeks with placebo (11 patients) or with donepezil $10 \mathrm{mg} /$ day (10 patients) and, after a 4 -week washout phase, were treated for 6 weeks with the reverse medication. The deterioration in cognition of patients at baseline was only mild $(24 \leq$ MMSE $\leq 30)$. The trial was completed by all patients of the placebo group and by 8 patients treated with donepezil. Efficacy analyses revealed no significant changes in a broad range of standardized tests for memory, executive function, attention and behavioural aspects. A slight improvement was observed in two tests of memory function. On the other hand, a worsening in motor ADL occurred. Post-hoc testing marked an important influence of dopaminergic co-medication on ADL function and memory. Thus, in this study it was impossible to differentiate whether worsening in motor ADL function was primarily caused by insufficient drug medication or due to progression of parkinsonian syndromes. Litvan et al. [141] reported 3 patients who did not tolerate the full dose of donepezil because of considerable deterioration of motor functions. The frequency of diarrhoea was higher in the donepezil phase compared with the placebo period. One open-label trial (class IV) with 6 patients (mean age: 67 years) failed to show improvement of cognitive functions after 3 months of treatment with donepezil ( $10 \mathrm{mg} /$ day) [142]. The neuropsychological performance at baseline $(18 \leq$ MMSE $\leq 28)$ was compared with that after the 3 -month treatment phase, and no changes in cognition, motor scores and ADLs were found. No significant adverse events during the treatment phase with donepezil were stated.

Treatment with ChEIs
In summary, in PSP the outcome of 1 class I study indicates a minor improvement in some but not all tests of memory function after treatment with donepezil. Therefore, the results are not unequivocal. Moreover, there is an increased risk of gastrointestinal side effects. The weak beneficial effect on memory functions was not supported in an open-label trial with a small sample size. Studies (class III) with the short acting ChEI physostigmine noted amelioration in memory and frontal sensitive tests. Unfortunately, the number of patients was very low in these 2 investigations. In addition, it is questionable whether the doses used in these studies were sufficient to have any central effect $[26,34]$. Therefore, the level of evidence for treating PSP with donepezil and physostigmine is poor and needs further verification in studies with sufficient numbers of patients.

\section{Corticobasal Degeneration}

Patients with CBD may present with a wide range of different symptoms, which leads to poor diagnostic accuracy [143]. Clinical characteristics are asymmetric signs of parkinsonism, usually from the akinetic-rigid syndrome with or without tremor, and asymmetrical cortical signs $[144,145]$. Similarly to PSP there is usually only little or no beneficial response to levodopa therapy [146]. Dystonia, dysarthria as well as alien limb phenomenon are common in CBD [147-150]. Abnormalities of eye movements may occur [151]. Most prominent, however, and helpful for differential diagnosis, is the occurrence of apraxia presented in up to $70 \%$ of patients with clinically diagnosed CBD [152]. Ideomotor and limb-kinetic apraxia are the most striking features of CBD [153, 154 ] and both forms of apraxia can be combined in the same limb [123].

Dementia is one of the most common signs of pathologically confirmed cases with CBD $[155,156]$. Cognitive deficits are present early in the disease course, sometimes even before the onset of motor symptoms [157]. Estimation of the dementia rate in patients with $\mathrm{CBD}$ varies between 25 and $100 \%$ [144, 156]. Cognitive symptoms in CBD share common clinical and pathological features with PSP and with fronto-temporal dementia (FTD) [158-160]. Impairments of frontal lobe functions, e.g. problems in set shifting [161] or reduced word fluency [162] as well as constructional apraxia are also usual findings in CBD $[163,164]$. Impairment in handwriting occurs frequently and is not exclusively related to apraxia [165]. Episodic memory function disturbance seems to be 
less severe than that seen in $\mathrm{AD}$ [166]. It is supposed that disturbances in episodic memory are caused by frontal rather than hippocampal loss of function [164]. However, further verification of this hypothesis is needed. Speech problems have been reported in CBD and it is now generally accepted that aphasia may either occur as one of the initial symptoms or in the course of the disease $[157,167]$. Additionally, many patients suffer from neuropsychiatric disturbances like depression, apathy, irritability and agitation [168].

Atrophy in CBD is usually cortical and subcortical in nature. Loss of neurons and gliosis, especially astrocytic plaques, can be found in the pars compacta of the substantia nigra as well as in the brainstem and cerebral grey matter [145]. Cortical atrophy is mainly asymmetric and affects the superior parietal and frontal lobes with relative sparing of the temporal and occipital lobes associated with the presence of swollen achromatic cells and secondary degeneration of the corticospinal tracts [169, 170]. Studies of tau protein demonstrate that CBD shares a common genetic background with PSP and primary progressive aphasia $[171,172]$. Cholinergic neuropathological changes in CBD have been found in the nucleus basalis of Meynert, as well as the dorsolateral tegmental and the pedunculopontine tegmental nuclei [27]. Reduction of cholinergic neurons and activity in the nucleus basalis of Meynert seem to be more pronounced than in PSP [27]. However, reports of treatment effects with ChEIs in patients with CBD are lacking. The symptomatology and neuropathology of CBD show great overlap with FTD [173]. Cases presenting with progressive aphasia and the behavioural variant of FTD frequently develop features of CBD [157] or had CBD neuropathology [158, 160]. Therefore, some authors claimed that CBD should be considered as part of the Pick complex [160]. One study examining the use of rivastigmine in FTD [174] gives rise to the expectation that treatment may reduce neuropsychiatric symptoms but does not primarily affect cognition.

\section{Discussion}

Up to now the aetiology of dementia in parkinsonian syndromes is only partly understood. The greatest similarity exists between DLB and PDD, where the classification of the diagnosis depends mainly on the sequence of appearance of symptoms [76]. In contrast to $\mathrm{AD}$, reduction in cognition mostly concentrates on executive functions, and here especially on visuospatial functions, oc- curring very early in the course of the disease. Neuropsychiatric symptoms are characteristic for dementia in parkinsonian disorders, particularly depression, hallucination, apathy, disinhibition and altered sleep behaviour.

In all the discussed disorders, PDD, DLB, PSP and CBD, the cholinergic system is affected [16, 27, 29, 34]. However, the benefit of ChEIs on dementia might differ between the different entities. ChEIs may be moderately effective to increase cognition in PDD and rivastigmine may reduce behavioural disturbances in these patients. Further verification of these aspects is needed. Varying treatment effects of ChEIs in these patient groups may be additionally caused by blockage of different cholinesterase subtypes (i.e. acetyl- and butyrylcholinesterase). The amount and relation of these 2 enzymes have been shown to change in the course of $\mathrm{AD}$, and it may well be that a specific relation of these metabolizing systems may account for the different responses within PDD $[175,176]$. Recently, the ChEI rivastigmine was authorized for the treatment of mild to moderately severe PDD. At present, there are only some hints of the beneficial effect of cholinergic treatment on cognition in DLB. However, behavioural aspects might be positively affected, which may increase the quality of the patient's life and reduce caregiver distress. Heterogeneity of patient samples is likely to be one reason for the lack of evidence of effects of treatment with ChEIs on cognition in DLB. The definition may include various subgroups of patients, e.g. patients with and without additional Alzheimer pathological cortical changes [102], which differ in severity and progression of the disease. Identification of clinical characteristics of patients and definition of subgroups that will respond well to ChEIs medication are needed. Furthermore, it can only be suggested that patients with PSP and cognitive disturbances did not benefit from use of ChEIs. Cognitive impairment in PSP has been attributed to prefrontal deafferation and lesions and only secondarily to degeneration of the ascending cholinergic basal or striatal neurons [25]. In contrast, cognitive dysfunction may be related to impairment of the ascending cholinergic system [137], which can also cause diverse action of pharmacological intervention with ChEIs. Only studies with low patient numbers have been performed. A systematic study on cholinergic treatment in CBD has not been conducted.

When discussing the effect of ChEIs in parkinsonian syndromes associated with dementia, some key issues should be considered. (i) To date there are only few double-blind randomized placebo-controlled trials in a rep- 
resentative population. (ii) Improvements in the MMSE and ADAScog scores were about 2 points, which rises the question of clinical relevance and of subgroups which benefit most (or not) from medication. These scales also primarily focus on aspects of cognitive decline in $\mathrm{AD}$; therefore, screening instruments which assess other core symptoms of dementia in parkinsonian syndromes are needed. These should also include improvement in clinical impression as in some class I studies $[61,62,103]$ and in ADL function [60]. (iii) Although there is some data that ChEIs do not worsen parkinsonian motor symptoms in PDD and DLB, it is indispensable for future trials to concentrate on the exact registration of these adverse effects. Most side effects are gastrointestinal in nature (e.g. nausea, vomiting) and do not obviously differ between treatment and placebo group in class I studies, but there was often a tendency of a higher patient dropout rate under drug medication. However, reported adverse events may be merely transient in duration and therefore inferior to the overall beneficial effect of ChEIs. (iv) Randomized controlled trials that directly compare different ChEIs in a representative population as well as the proof of long-term efficacy are still lacking and have to be investigated in future trials.

\section{Acknowledgements}

This study was supported by Novartis GmbH. We thank Andrea Quintero for her very helpful comments concerning the preparation of the manuscript.

\section{References}

1 Levy G, Tang MX, Louis ED, Cote LJ, Alfaro B, Mejia H, Stern Y, Marder K: The association of incident dementia with mortality in PD. Neurology 2002;59:1708-1713.

2 Hughes TA, Ross HF, Mindham RH, Spokes EG: Mortality in Parkinson's disease and its association with dementia and depression. Acta Neurol Scand 2004;110:118-123.

- 3 Schrag A, Jahanshahi M, Quinn N: What contributes to quality of life in patients with Parkinson's disease? J Neurol Neurosurg Psychiatry 2000;69:308-312

-4 Jellinger K, Danielczyk W, Fischer P, Gabriel E: Clinicopathological analysis of dementia disorders in the elderly. J Neurol Sci 1990;95: 239-258.

5 Jellinger KA: Age-associated prevalence and risk factors of Lewy body pathology in a general population. Acta Neuropathol (Berl) 2003;106:383-384.

-6 Quinn NP: How to diagnose multiple system atrophy. Mov Disord 2005;20(suppl 12):S5S10.

7 Bruni AC, Takahashi-Fujigasaki J, Maltecca F, Foncin JF, Servadio A, Casari G, D’Adamo P, Maletta R, Curcio SA, De Michele G, Filla A, El Hachimi KH, Duyckaerts C: Behavioral disorder, dementia, ataxia, and rigidity in a large family with TATA box-binding protein mutation. Arch Neurol 2004;61:13141320.

8 Reynolds NC Jr: The diagnosis of Huntington's disease. Neurology 1987;37:1091.

$\triangleright 9$ Willemsen R, Mientjes E, Oostra BA: FXTAS: a progressive neurologic syndrome associated with Fragile X premutation. Curr Neurol Neurosci Rep 2005;5:405-410.
10 Kertesz A: The clinical spectrum of dementia in movement disorders; in Bedard MA, Agid Y, Chouinard S, Fahn S, Korczyn AD, Lesperance P (eds): Mental and Behavioral Dysfunction in Movement Disorders. Totwa, Humana Press, 2003, pp 223-229.

11 Fuchs GA, Gemende I, Herting B, Lemke MR, Oehlwein C, Reichmann H, Rieke J, Emmans D, Volkmann J: Dementia in idiopathic Parkinson's syndrome. J Neurol 2004; 251(suppl 6):28-32.

12 Harding AJ, Halliday GM: Cortical Lewy body pathology in the diagnosis of dementia. Acta Neuropathol (Berl) 2001;102:355-363.

$\checkmark 13$ Aarsland D, Perry R, Brown A, Larsen JP, Ballard C: Neuropathology of dementia in Parkinson's disease: a prospective, community-based study. Ann Neurol 2005;58:773776.

14 Mastaglia FL, Johnsen RD, Byrnes ML, Kakulas BA: Prevalence of amyloid-beta deposition in the cerebral cortex in Parkinson's disease. Mov Disord 2003;18:81-86.

15 Hurtig HI, Trojanowski JQ, Galvin J, Ewbank D, Schmidt ML, Lee VM, Clark CM, Glosser G, Stern MB, Gollomp SM, Arnold SE: Alpha-synuclein cortical Lewy bodies correlate with dementia in Parkinson's disease. Neurology 2000;54:1916-1921.

16 Tiraboschi P, Hansen LA, Alford M, Sabbagh MN, Schoos B, Masliah E, Thal LJ, CoreyBloom J: Cholinergic dysfunction in diseases with Lewy bodies. Neurology 2000;54:407411.

17 Hilker R, Thomas AV, Klein JC, Weisenbach S, Kalbe E, Burghaus L, Jacobs AH, Herholz $\mathrm{K}$, Heiss WD: Dementia in Parkinson disease: functional imaging of cholinergic and dopaminergic pathways. Neurology 2005; 65:1716-1722.
18 Shinotoh H, Namba H, Yamaguchi M, Fukushi K, Nagatsuka S, Iyo M, Asahina M, Hattori $\mathrm{T}$, Tanada $\mathrm{S}$, Irie $\mathrm{T}$ : In vivo mapping of brain cholinergic function in Parkinson's disease and progressive supranuclear palsy. Adv Neurol 2001;86:249-255.

19 Zgaljardic DJ, Foldi NS, Borod JC: Cognitive and behavioral dysfunction in Parkinson's disease: neurochemical and clinicopathological contributions. J Neural Transm 2004; 111:1287-1301.

20 Pillon B, Czernecki V, Dubois B: Dopamine and cognitive function. Curr Opin Neurol 2003;16(suppl 2):S17-S22.

21 Bohnen NI, Kaufer DI, Ivanco LS, Lopresti B, Koeppe RA, Davis JG, Mathis CA, Moore RY, DeKosky ST: Cortical cholinergic function is more severely affected in parkinsonian dementia than in Alzheimer disease: an in vivo positron emission tomographic study. Arch Neurol 2003;60:1745-1748.

22 Miyasaki JM, Shannon K, Voon V, Ravina B, Kleiner-Fisman G, Anderson K, Shulman LM, Gronseth G, Weiner WJ: Practice Parameter: Evaluation and treatment of depression, psychosis, and dementia in Parkinson disease (an evidence-based review) - Report of the Quality Standards Subcommittee of the American Academy of Neurology. Neurology 2006;66:966-1002.

-23 Kuhl DE, Minoshima S, Fessler JA, Frey KA, Foster NL, Ficaro EP, Wieland DM, Koeppe RA: In vivo mapping of cholinergic terminals in normal aging, Alzheimer's disease, and Parkinson's disease. Ann Neurol 1996; 40:399-410.

24 Litvan I: Cholinergic approaches to the treatment of progressive supranuclear palsy. J Neural Transm Suppl 1994;42:275-281. 
-25 Litvan I, Blesa R, Clark K, Nichelli P, Atack JR, Mouradian MM, Grafman J, Chase TN: Pharmacological evaluation of the cholinergic system in progressive supranuclear palsy. Ann Neurol 1994;36:55-61.

-26 Atack JR, Litvan I, Thal LJ, May C, Rapoport SI, Chase TN: Cerebrospinal fluid acetylcholinesterase in progressive supranuclear palsy: reduced activity relative to normal subjects and lack of inhibition by oral physostigmine. J Neurol Neurosurg Psychiatry 1991;54:832-835.

-27 Kasashima S, Oda Y: Cholinergic neuronal loss in the basal forebrain and mesopontine tegmentum of progressive supranuclear palsy and corticobasal degeneration. Acta Neuropathol (Berl) 2003;105:117-124.

$\checkmark 28$ Liberini P, Valerio A, Memo M, Spano PF: Lewy-body dementia and responsiveness to cholinesterase inhibitors: a paradigm for heterogeneity of Alzheimer's disease? Trends Pharmacol Sci 1996;17:155-160.

-29 Perry EK, Irving D, Kerwin JM, McKeith IG, Thompson P, Collerton D, Fairbairn AF, Ince PG, Morris CM, Cheng AV: Cholinergic transmitter and neurotrophic activities in Lewy body dementia: similarity to Parkinson's and distinction from Alzheimer disease. Alzheimer Dis Assoc Disord 1993;7: 69-79.

$\checkmark 30$ Samuel W, Caligiuri M, Galasko D, Lacro J, Marini M, McClure FS, Warren K, Jeste DV: Better cognitive and psychopathologic response to donepezil in patients prospectively diagnosed as dementia with Lewy bodies: a preliminary study. Int J Geriatr Psychiatry 2000;15:794-802.

-31 Maidment ID, Fox C, Boustani M: A review of studies describing the use of acetyl cholinesterase inhibitors in Parkinson's disease dementia. Acta Psychiatr Scand 2005;111:403409.

-32 McKeith IG, Wesnes KA, Perry E, Ferrara R: Hallucinations predict attentional improvements with rivastigmine in dementia with Lewy bodies. Dement Geriatr Cogn Disord 2004;18:94-100.

-33 Simard M, van Reekum R: The acetylcholinesterase inhibitors for treatment of cognitive and behavioral symptoms in dementia with Lewy bodies. J Neuropsychiatry Clin Neurosci 2004; 16:409-425.

$\checkmark 34$ Warren NM, Piggott MA, Perry EK, Burn DJ: Cholinergic systems in progressive supranuclear palsy. Brain 2005;128:239-249.

35 Wild R, Pettit T, Burns A: Cholinesterase inhibitors for dementia with Lewy bodies. Cochrane Database Syst Rev 2003:CD003672.

36 Maidment I, Fox C, Boustani M: Cholinesterase inhibitors for Parkinson's disease dementia. Cochrane Database Syst Rev 2006: CD004747.

-37 Wesnes KA, McKeith I, Edgar C, Emre M, Lane R: Benefits of rivastigmine on attention in dementia associated with Parkinson disease. Neurology 2005;65:1654-1656.
38 Kertzman C, Robinson DL, Litvan I: Effects of physostigmine on spatial attention in patients with progressive supranuclear palsy. Arch Neurol 1990;47:1346-1350.

39 Fogelson N, Kogan E, Korczyn AD, Giladi N, Shabtai H, Neufeld MY: Effects of rivastigmine on the quantitative EEG in demented Parkinsonian patients. Acta Neurol Scand 2003;107:252-255.

40 Lebert F, Pasquier F, Souliez L, Petit H: Tacrine efficacy in Lewy body dementia. Int J Geriatr Psychiatry 1998;13:516-519.

41 Wilcock GK, Scott MI: Tacrine for senile dementia of Alzheimer's or Lewy body type. Lancet 1994;344:544.

42 Aarsland D, Andersen K, Larsen JP, Lolk A, Nielsen H, Kragh-Sorensen P: Risk of dementia in Parkinson's disease: a communitybased, prospective study. Neurology 2001; 56:730-736.

43 Hobson P, Meara J: Risk and incidence of dementia in a cohort of older subjects with Parkinson's disease in the United Kingdom. Mov Disord 2004;19:1043-1049.

44 Bonelli SB, Ransmayr G, Steffelbauer M, Lukas T, Lampl C, Deibl M: L-dopa responsiveness in dementia with Lewy bodies, Parkinson disease with and without dementia. Neurology 2004;63:376-378.

45 Aarsland D, Andersen K, Larsen JP, Lolk A, Kragh-Sorensen P: Prevalence and characteristics of dementia in Parkinson disease: an 8-year prospective study. Arch Neurol 2003;60:387-392.

46 Green J, McDonald WM, Vitek JL, Evatt M, Freeman A, Haber M, Bakay RA, Triche S, Sirockman B, DeLong MR: Cognitive impairments in advanced PD without dementia. Neurology 2002;59:1320-1324.

47 Jacobs DM, Marder K, Cote LJ, Sano M, Stern Y, Mayeux R: Neuropsychological characteristics of preclinical dementia in Parkinson's disease. Neurology 1995;45:1691-1696.

48 Allain H, Lieury A, Thomas V, Reymann JM, Gandon JM, Belliard S: Explicit and procedural memory in Parkinson's disease. Biomed Pharmacother 1995;49:179-186.

49 Gilbert B, Belleville S, Bherer L, Chouinard S: Study of verbal working memory in patients with Parkinson's disease. Neuropsychology 2005;19:106-114.

50 Whittington CJ, Podd J, Kan MM: Recognition memory impairment in Parkinson's disease: power and meta-analyses. Neuropsychology 2000;14:233-246.

51 Hughes TA, Ross HF, Musa S, Bhattacherjee S, Nathan RN, Mindham RH, Spokes EG: A 10 -year study of the incidence of and factors predicting dementia in Parkinson's disease. Neurology 2000;54:1596-1602.

52 Apaydin H, Ahlskog JE, Parisi JE, Boeve BF, Dickson DW: Parkinson disease neuropathology: later-developing dementia and loss of the levodopa response. Arch Neurol 2002; 59:102-112.
53 Braak H, Ghebremedhin E, Rub U, Bratzke $\mathrm{H}$, Del Tredici K: Stages in the development of Parkinson's disease-related pathology. Cell Tissue Res 2004;318:121-134.

54 Braak H, Rub U, Jansen Steur EN, Del Tredici K, de Vos RA: Cognitive status correlates with neuropathologic stage in Parkinson disease. Neurology 2005;64:1404-1410.

$55 \mathrm{Hu}$ MT, White SJ, Chaudhuri KR, Morris RG, Bydder GM, Brooks DJ: Correlating rates of cerebral atrophy in Parkinson's disease with measures of cognitive decline. J Neural Transm 2001;108:571-580.

56 Summerfield C, Junque C, Tolosa E, Salgado-Pineda P, Gomez-Anson B, Marti MJ, Pastor P, Ramirez-Ruiz B, Mercader J: Structural brain changes in Parkinson disease with dementia: a voxel-based morphometry study. Arch Neurol 2005;62:281-285.

57 Burton EJ, McKeith IG, Burn DJ, Williams ED, O’Brien JT: Cerebral atrophy in Parkinson's disease with and without dementia: a comparison with Alzheimer's disease, dementia with Lewy bodies and controls. Brain 2004;127:791-800.

58 Nagano-Saito A, Washimi Y, Arahata Y, Kachi T, Lerch JP, Evans AC, Dagher A, Ito K: Cerebral atrophy and its relation to cognitive impairment in Parkinson disease. Neurology 2005;64:224-229.

59 Bohnen NI, Kaufer DI, Hendrickson R, Ivanco LS, Lopresti BJ, Constantine GM, Mathis C, Davis JG, Moore RY, DeKosky ST: Cognitive correlates of cortical cholinergic denervation in Parkinson's disease and parkinsonian dementia. J Neurol 2006;253:242-247.

60 Emre M, Aarsland D, Albanese A, Byrne EJ, Deuschl G, De Deyn PP, Durif F, Kulisevsky J, van Laar T, Lees A, Poewe W, Robillard A, Rosa MM, Wolters E, Quarg P, Tekin S, Lane R: Rivastigmine for dementia associated with Parkinson's disease. N Engl J Med 2004; 351:2509-2518.

61 Aarsland D, Laake K, Larsen JP, Janvin C: Donepezil for cognitive impairment in Parkinson's disease: a randomised controlled study. J Neurol Neurosurg Psychiatry 2002; 72:708-712.

62 Ravina B, Putt M, Siderowf A, Farrar JT, Gillespie M, Crawley A, Fernandez HH, Trieschmann MM, Reichwein S, Simuni T: Donepezil for dementia in Parkinson's disease: a randomised, double blind, placebo controlled, crossover study. J Neurol Neurosurg Psychiatry 2005;76:934-939.

63 Leroi I, Brandt J, Reich SG, Lyketsos CG, Grill S, Thompson R, Marsh L: Randomized placebo-controlled trial of donepezil in cognitive impairment in Parkinson's disease. Int J Geriatr Psychiatry 2004;19:1-8.

64 Thomas AJ, Burn DJ, Rowan EN, Littlewood E, Newby J, Cousins D, Pakrasi S, Richardson J, Sanders J, McKeith IG: A comparison of the efficacy of donepezil in Parkinson's disease with dementia and dementia with Lewy bodies. Int J Geriatr Psychiatry 2005; 20:938-944. 
-65 Aarsland D, Hutchinson M, Larsen JP: Cognitive, psychiatric and motor response to galantamine in Parkinson's disease with dementia. Int J Geriatr Psychiatry 2003;18: 937-941.

- 66 Poewe W, Wolters E, Emre M, Onofrj M, Hsu C, Tekin S, Lane R: Long-term benefits of rivastigmine in dementia associated with Parkinson's disease: an active treatment extension study. Mov Disord 2006;21:456461.

67 Giladi N, Shabtai H, Gurevich T, Benbunan B, Anca M, Korczyn AD: Rivastigmine (Exelon) for dementia in patients with Parkinson's disease. Acta Neurol Scand 2003;108: 368-373.

68 Hutchinson M, Fazzini E: Cholinesterase inhibition in Parkinson's disease. J Neurol Neurosurg Psychiatry 1996;61:324-325.

-69 Minett TS, Thomas A, Wilkinson LM, Daniel SL, Sanders J, Richardson J, Littlewood E, Myint P, Newby J, McKeith IG: What happens when donepezil is suddenly withdrawn? An open label trial in dementia with Lewy bodies and Parkinson's disease with dementia. Int J Geriatr Psychiatry 2003;18:988993.

70 Reading PJ, Luce AK, McKeith IG: Rivastigmine in the treatment of parkinsonian psychosis and cognitive impairment: preliminary findings from an open trial. Mov Disord 2001;16:1171-1174.

-71 Werber EA, Rabey JM: The beneficial effect of cholinesterase inhibitors on patients suffering from Parkinson's disease and dementia. J Neural Transm 2001;108:1319-1325.

-72 Putt ME, Ravina B: Randomized, placebocontrolled, parallel group versus crossover study designs for the study of dementia in Parkinson's disease. Control Clin Trials 2002;23:111-126.

-73 Turner RS, D'Amato CJ, Chervin RD, Blaivas M: The pathology of REM sleep behavior disorder with comorbid Lewy body dementia. Neurology 2000;55:1730-1732.

-74 Del Ser T, McKeith I, Anand R, Cicin-Sain A, Ferrara R, Spiegel R: Dementia with lewy bodies: findings from an international multicentre study. Int J Geriatr Psychiatry 2000; 15:1034-1045.

75 Holmes C, Cairns N, Lantos P, Mann A: Validity of current clinical criteria for Alzheimer's disease, vascular dementia and dementia with Lewy bodies. Br J Psychiatry 1999;174: 45-50.

76 McKeith IG, Dickson DW, Lowe J, et al: Diagnosis and management of dementia with Lewy bodies: third report of the DLB consortium. Neurology 2005;65:1863-1872.

-77 McKeith IG, Ballard CG, Perry RH, Ince PG, O'Brien JT, Neill D, Lowery K, Jaros E, Barber R, Thompson P, Swann A, Fairbairn AF, Perry EK: Prospective validation of consensus criteria for the diagnosis of dementia with Lewy bodies. Neurology 2000;54:10501058.
78 Geser F, Wenning GK, Poewe W, McKeith I: How to diagnose dementia with Lewy bodies: state of the art. Mov Disord 2005;20 (suppl 12):S11-S20.

79 Aarsland D, Ballard CG, Halliday G: Are Parkinson's disease with dementia and dementia with Lewy bodies the same entity? J Geriatr Psychiatry Neurol 2004;17:137-145.

80 Lambon Ralph MA, Powell J, Howard D, Whitworth AB, Garrard P, Hodges JR: Semantic memory is impaired in both dementia with Lewy bodies and dementia of Alzheimer's type: a comparative neuropsychological study and literature review. J Neurol Neurosurg Psychiatry 2001;70:149-156.

81 Serrano C, Garcia-Borreguero D: Fluctuations in cognition and alertness in Parkinson's disease and dementia. Neurology 2004, 63:S31-S34.

82 Ballard CG, Ayre G, O’Brien J, Sahgal A, McKeith IG, Ince PG, Perry RH: Simple standardised neuropsychological assessments aid in the differential diagnosis of dementia with Lewy bodies from Alzheimer's disease and vascular dementia. Dement Geriatr Cogn Disord 1999;10:104-108.

83 Calderon J, Perry RJ, Erzinclioglu SW, Berrios GE, Dening TR, Hodges JR: Perception, attention, and working memory are disproportionately impaired in dementia with Lewy bodies compared with Alzheimer's disease. J Neurol Neurosurg Psychiatry 2001; 70:157-164.

84 Galasko D: Lewy bodies and dementia. Curr Neurol Neurosci Rep 2001;1:435-441.

85 Marui W, Iseki E, Nakai T, Miura S, Kato M, Ueda K, Kosaka K: Progression and staging of Lewy pathology in brains from patients with dementia with Lewy bodies. J Neurol Sci 2002;195:153-159.

86 Hansen LA, Samuel W: Criteria for Alzheimer's disease and the nosology of dementia with Lewy bodies. Neurology 1997;48:126132.

87 Dickson DW, Ruan D, Crystal H, Mark MH, Davies P, Kress Y, Yen SH: Hippocampal degeneration differentiates diffuse Lewy body disease (DLBD) from Alzheimer's disease: light and electron microscopic immunocytochemistry of CA2-3 neurites specific to DLBD. Neurology 1991;41:1402-1409.

88 Barber R, Gholkar A, Scheltens P, Ballard C, McKeith IG, O’Brien JT: MRI volumetric correlates of white matter lesions in dementia with Lewy bodies and Alzheimer's disease. Int J Geriatr Psychiatry 2000;15:911916.

89 O’Brien JT, Paling S, Barber R, Williams ED, Ballard C, McKeith IG, Gholkar A, Crum WR, Rossor MN, Fox NC: Progressive brain atrophy on serial MRI in dementia with Lewy bodies, AD, and vascular dementia. Neurology 2001;56:1386-1388.
90 Colloby SJ, Fenwick JD, Williams ED, Paling SM, Lobotesis K, Ballard C, McKeith I, O'Brien JT: A comparison of (99m)Tc-HMPAO SPET changes in dementia with Lewy bodies and Alzheimer's disease using statistical parametric mapping. Eur J Nucl Med Mol Imaging 2002;29:615-622.

-91 Pantel J, Schonknecht P, Essig M, Schroder $\mathrm{J}$ : Distribution of cerebral atrophy assessed by magnetic resonance imaging reflects patterns of neuropsychological deficits in Alzheimer's dementia. Neurosci Lett 2004; 361:17-20.

92 Ishii K, Hosaka K, Mori T, Mori E: Comparison of FDG-PET and IMP-SPECT in patients with dementia with Lewy bodies. Ann Nucl Med 2004;18:447-451.

-93 Gilman S, Koeppe RA, Little R, An H, Junck L, Giordani B, Persad C, Heumann M, Wernette K: Differentiation of Alzheimer's disease from dementia with Lewy bodies utilizing positron emission tomography with [18F]fluorodeoxyglucose and neuropsychological testing. Exp Neurol 2005; 191(suppl 1):S95-S103.

94 Lobotesis K, Fenwick JD, Phipps A, Ryman A, Swann A, Ballard C, McKeith IG, O'Brien JT: Occipital hypoperfusion on SPECT in dementia with Lewy bodies but not AD. Neurology 2001;56:643-649.

-95 Shimizu S, Hanyu H, Kanetaka H, Iwamoto T, Koizumi K, Abe K: Differentiation of dementia with Lewy bodies from Alzheimer's disease using brain SPECT. Dement Geriatr Cogn Disord 2005;20:25-30.

96 Donnemiller E, Heilmann J, Wenning GK, Berger W, Decristoforo C, Moncayo R, Poewe W, Ransmayr G: Brain perfusion scintigraphy with 99mTc-HMPAO or 99mTc-ECD and 123I-beta-CIT singlephoton emission tomography in dementia of the Alzheimer type and diffuse Lewy body disease. Eur J Nucl Med 1997;24:320325.

-97 Colloby SJ, O’Brien JT, Fenwick JD, Firbank MJ, Burn DJ, McKeith IG, Williams ED: The application of statistical parametric mapping to 123I-FP-CIT SPECT in dementia with Lewy bodies, Alzheimer's disease and Parkinson's disease. Neuroimage 2004; 23:956-966.

-98 Samuel W, Alford M, Hofstetter CR, Hansen L: Dementia with Lewy bodies versus pure Alzheimer disease: differences in cognition, neuropathology, cholinergic dysfunction, and synapse density. J Neuropathol Exp Neurol 1997;56:499-508.

-99 Ballard C, Piggott M, Johnson M, Cairns N, Perry R, McKeith I, Jaros E, O’Brien J, Holmes C, Perry E: Delusions associated with elevated muscarinic binding in dementia with Lewy bodies. Ann Neurol 2000;48: 868-876.

100 Fabbrini G, Barbanti P, Aurilia C, Pauletti C, Lenzi GL, Meco G: Donepezil in the treatment of hallucinations and delusions in Parkinson's disease. Neurol Sci 2002;23:41-43. 
101 Kurita A, Ochiai Y, Kono Y, Suzuki M, Inoue K: The beneficial effect of donepezil on visual hallucinations in three patients with Parkinson's disease. J Geriatr Psychiatry Neurol 2003;16:184-188.

- 102 McKeith I, Mintzer J, Aarsland D, Burn D, Chiu H, Cohen-Mansfield J, Dickson D, Dubois B, Duda JE, Feldman H, Gauthier S, Halliday G, Lawlor B, Lippa C, Lopez OL, Carlos MJ, O’Brien J, Playfer J, Reid W: Dementia with Lewy bodies. Lancet Neurol 2004;3:19-28

103 McKeith I, Del Ser T, Spano P, Emre M, Wesnes K, Anand R, Cicin-Sain A, Ferrara $R$, Spiegel R: Efficacy of rivastigmine in dementia with Lewy bodies: a randomised, double-blind, placebo-controlled international study. Lancet 2000;356:2031-2036.

104 Beversdorf DQ, Warner JL, Davis RA, Sharma UK, Nagaraja HN, Scharre DW: Donepezil in the treatment of dementia with Lewy bodies. Am J Geriatr Psychiatry 2004;12:542-544.

- 105 Querfurth HW, Allam GJ, Geffroy MA, Schiff HB, Kaplan RF: Acetylcholinesterase inhibition in dementia with Lewy bodies: results of a prospective pilot trial. Dement Geriatr Cogn Disord 2000;11:314-321.

- 106 Edwards KR, Hershey L, Wray L, Bednarczyk EM, Lichter D, Farlow M, Johnson S: Efficacy and safety of galantamine in patients with dementia with Lewy bodies: a 12-week interim analysis. Dement Geriatr Cogn Disord 2004;17(suppl 1):40-48.

107 Grace JB, Walker MP, McKeith IG: A comparison of sleep profiles in patients with dementia with Lewy bodies and Alzheimer's disease. Int J Geriatr Psychiatry 2000;15: 1028-1033.

108 Wesnes KA, McKeith IG, Ferrara R, Emre M, Del Ser T, Spano PF, Cicin-Sain A, Anand R, Spiegel R: Effects of rivastigmine on cognitive function in dementia with Lewy bodies: a randomised placebo-controlled international study using the cognitive drug research computerised assessment system. Dement Geriatr Cogn Disord 2002;13:183-192.

-109 McKeith IG, Grace JB, Walker Z, Byrne EJ, Wilkinson D, Stevens T, Perry EK: Rivastigmine in the treatment of dementia with Lewy bodies: preliminary findings from an open trial. Int J Geriatr Psychiatry 2000;15: 387-392.

-110 Grace J, Daniel S, Stevens T, Shankar KK, Walker Z, Byrne EJ, Butler S, Wilkinson D, Woolford J, Waite J, McKeith IG: Longterm use of rivastigmine in patients with dementia with Lewy bodies: an open-label trial. Int Psychogeriatr 2001;13:199-205.

- 111 McKeith IG, Galasko D, Kosaka K, et al: Consensus guidelines for the clinical and pathologic diagnosis of dementia with Lewy bodies (DLB): report of the consortium on DLB international workshop. Neurology 1996;47:1113-1124.
112 Rehman HU: Progressive supranuclear palsy. Postgrad Med J 2000;76:333-336.

113 Poewe W, Wenning G: The differential diagnosis of Parkinson's disease. Eur J Neurol 2002;9(suppl 3):23-30.

114 Menza MA, Cocchiola J, Golbe LI: Psychiatric symptoms in progressive supranuclear palsy. Psychosomatics 1995;36:550-554.

115 Millar D, Griffiths P, Zermansky AJ, Burn DJ: Characterizing behavioral and cognitive dysexecutive changes in progressive supranuclear palsy. Mov Disord 2006;21: 199-207.

116 Esmonde T, Giles E, Gibson M, Hodges JR: Neuropsychological performance, disease severity, and depression in progressive supranuclear palsy. J Neurol 1996;243:638643.

117 Birdi S, Rajput AH, Fenton M, Donat JR, Rozdilsky B, Robinson C, Macaulay R, George D: Progressive supranuclear palsy diagnosis and confounding features: report on 16 autopsied cases. Mov Disord 2002;17: 1255-1264.

118 Dubois B, Slachevsky A, Pillon B, Beato R, Villalponda JM, Litvan I: 'Applause sign' helps to discriminate PSP from FTD and PD. Neurology 2005;64:2132-2133.

119 Litvan I: Cognitive disturbances in progressive supranuclear palsy. J Neural Transm Suppl 1994;42:69-78.

120 Pillon B, Dubois B, Lhermitte F, Agid Y: Heterogeneity of cognitive impairment in progressive supranuclear palsy, Parkinson's disease, and Alzheimer's disease. Neurology 1986;36:1179-1185.

121 Bak TH, Crawford LM, Hearn VC, Mathuranath PS, Hodges JR: Subcortical dementia revisited: similarities and differences in cognitive function between progressive supranuclear palsy (PSP), corticobasal degeneration (CBD) and multiple system atrophy (MSA). Neurocase 2005;11: 268-273.

122 Lange KW, Tucha O, Alders GL, Preier M, Csoti I, Merz B, Mark G, Herting B, Fornadi F, Reichmann $H$, Vieregge $P$, Reiners K, Becker G, Naumann M: Differentiation of parkinsonian syndromes according to differences in executive functions. J Neural Transm 2003;110:983-995.

123 Zadikoff C, Lang AE: Apraxia in movement disorders. Brain 2005;128:1480-1497.

124 Soliveri P, Piacentini S, Paridi D, Testa D, Carella F, Girotti F: Distal-proximal differences in limb apraxia in corticobasal degeneration but not progressive supranuclear palsy. Neurol Sci 2003;24:213-214.

125 Pharr V, Uttl B, Stark M, Litvan I, Fantie B, Grafman J: Comparison of apraxia in corticobasal degeneration and progressive supranuclear palsy. Neurology 2001;56:957963.
126 Soliveri P, Piacentini S, Girotti F: Limb apraxia and cognitive impairment in progressive supranuclear palsy. Neurocase 2005;11:263-267.

-127 Papapetropoulos S, Gonzalez J, Mash DC: Natural history of progressive supranuclear palsy: a clinicopathologic study from a population of brain donors. Eur Neurol 2005; 54:1-9.

128 Arai T, Ikeda K, Akiyama H, Shikamoto Y, Tsuchiya K, Yagishita S, Beach T, Rogers J, Schwab C, McGeer PL: Distinct isoforms of tau aggregated in neurons and glial cells in brains of patients with Pick's disease, corticobasal degeneration and progressive supranuclear palsy. Acta Neuropathol (Berl) 2001;101:167-173.

129 Brenneis C, Seppi K, Schocke M, Benke T, Wenning GK, Poewe W: Voxel based morphometry reveals a distinct pattern of frontal atrophy in progressive supranuclear palsy. J Neurol Neurosurg Psychiatry 2004;75: 246-249.

130 Cervos-Navarro J, Schumacher K: Neurofibrillary pathology in progressive supranuclear palsy (PSP). J Neural Transm Suppl 1994;42:153-164.

131 Verny M, Duyckaerts C, Agid Y, Hauw JJ: The significance of cortical pathology in progressive supranuclear palsy: clinicopathological data in 10 cases. Brain 1996; 119:1123-1136.

132 Cordato NJ, Pantelis C, Halliday GM, Velakoulis D, Wood SJ, Stuart GW, Currie J, Soo M, Olivieri G, Broe GA, Morris JG: Frontal atrophy correlates with behavioural changes in progressive supranuclear palsy. Brain 2002;125:789-800.

133 Bigio EH, Brown DF, White CL 3rd: Progressive supranuclear palsy with dementia: cortical pathology. J Neuropathol Exp Neurol 1999;58:359-364.

$\checkmark 134$ Cordato NJ, Halliday GM, Harding AJ, Hely MA, Morris JG: Regional brain atrophy in progressive supranuclear palsy and Lewy body disease. Ann Neurol 2000;47: 718-728.

135 Albert ML, Feldman RG, Willis AL: The 'subcortical dementia' of progressive supranuclear palsy. J Neurol Neurosurg Psychiatry 1974;37:121-130.

136 Kompoliti K, Goetz CG, Litvan I, Jellinger $\mathrm{K}$, Verny M: Pharmacological therapy in progressive supranuclear palsy. Arch Neurol 1998;55:1099-1102.

137 Nardone R, Florio I, Lochner P, Tezzon F: Cholinergic cortical circuits in Parkinson's disease and in progressive supranuclear palsy: a transcranial magnetic stimulation study. Exp Brain Res 2005;163:128-131.

138 Asahina M, Suhara T, Shinotoh H, Inoue O, Suzuki K, Hattori T: Brain muscarinic receptors in progressive supranuclear palsy and Parkinson's disease: a positron emission tomographic study. J Neurol Neurosurg Psychiatry 1998;65:155-163. 
139 Litvan I, Gomez C, Atack JR, Gillespie M, Kask AM, Mouradian MM, Chase TN: Physostigmine treatment of progressive supranuclear palsy. Ann Neurol 1989;26: 404-407.

-140 Blin J, Mazetti P, Mazoyer B, Rivaud S, Ben Ayed S, Malapani C, Pillon B, Agid Y: Does the enhancement of cholinergic neurotransmission influence brain glucose kinetics and clinical symptomatology in progressive supranuclear palsy? Brain 1995; 118:1485-1495.

- 141 Litvan I, Phipps M, Pharr VL, Hallett M, Grafman J, Salazar A: Randomized placebo-controlled trial of donepezil in patients with progressive supranuclear palsy. Neurology 2001;57:467-473.

142 Fabbrini G, Barbanti P, Bonifati V, Colosimo C, Gasparini M, Vanacore N, Meco G: Donepezil in the treatment of progressive supranuclear palsy. Acta Neurol Scand 2001;103:123-125.

143 Hughes AJ, Daniel SE, Ben Shlomo Y, Lees AJ: The accuracy of diagnosis of parkinsonian syndromes in a specialist movement disorder service. Brain 2002;125:861-870.

144 Kompoliti K, Goetz CG, Boeve BF, Maraganore DM, Ahlskog JE, Marsden CD, Bhatia KP, Greene PE, Przedborski S, Seal EC, Burns RS, Hauser RA, Gauger LL, Factor SA, Molho ES, Riley DE: Clinical presentation and pharmacological therapy in corticobasal degeneration. Arch Neurol 1998; 55:957-961.

145 Watts RL, Mirra SS, Richardson EP: Corticobasal ganglionic degeneration; in Marsden CD, Fahn S (eds): Movement Disorders 3. Oxford, Butterworth-Heinemann, 1994, pp 282-299.

146 Lang AE: Treatment of progressive supranuclear palsy and corticobasal degeneration. Mov Disord 2005;20(suppl 12):S83S91.

147 Doody RS, Jankovic J: The alien hand and related signs. J Neurol Neurosurg Psychiatry 1992;55:806-810.

-148 Ozsancak C, Auzou P, Hannequin D: Dysarthria and orofacial apraxia in corticobasal degeneration. Mov Disord 2000;15:905910.

- 149 Thumler BH, Urban PP, Davids E, Siessmeier M, Schreckenberger T, Benz P, Stoeter P, Bartenstein P, Hopf HC: Dysarthria and pathological laughter/crying as presenting symptoms of corticobasal-ganglionic degeneration syndrome. J Neurol 2003;250: 1107-1108.

150 Vanek Z, Jankovic J: Dystonia in corticobasal degeneration. Mov Disord 2001;16: 252-257.
151 Rivaud-Pechoux S, Vidailhet M, Gallouedec G, Litvan I, Gaymard B, PierrotDeseilligny C: Longitudinal ocular motor study in corticobasal degeneration and progressive supranuclear palsy. Neurology 2000;54:1029-1032.

152 Leiguarda R, Lees AJ, Merello M, Starkstein $\mathrm{S}$, Marsden CD: The nature of apraxia in corticobasal degeneration. J Neurol Neurosurg Psychiatry 1994;57:455-459.

153 Leiguarda R, Merello M, Balej J: Apraxia in corticobasal degeneration. Adv Neurol 2000;82:103-121.

154 Leiguarda RC, Pramstaller PP, Merello M, Starkstein S, Lees AJ, Marsden CD: Apraxia in Parkinson's disease, progressive supranuclear palsy, multiple system atrophy and neuroleptic-induced parkinsonism. Brain 1997;120:75-90.

155 Grimes DA, Lang AE, Bergeron CB: Dementia as the most common presentation of cortical-basal ganglionic degeneration. Neurology 1999;53:1969-1974.

156 Schneider JA, Watts RL, Gearing M, Brewer RP, Mirra SS: Corticobasal degeneration: neuropathologic and clinical heterogeneity. Neurology 1997;48:959-969.

157 Kertesz A, Martinez-Lage P, Davidson W, Munoz DG: The corticobasal degeneration syndrome overlaps progressive aphasia and frontotemporal dementia. Neurology 2000; 55:1368-1375.

158 Ferrer I, Hernandez I, Boada M, Llorente A, Rey MJ, Cardozo A, Ezquerra M, Puig B: Primary progressive aphasia as the initial manifestation of corticobasal degeneration and unusual tauopathies. Acta Neuropathol (Berl) 2003;106:419-435

159 Kertesz A, Munoz D: Relationship between frontotemporal dementia and corticobasal degeneration/progressive supranuclear palsy. Dement Geriatr Cogn Disord 2004; 17:282-286.

160 Kertesz A, McMonagle P, Blair M, Davidson W, Munoz DG: The evolution and pathology of frontotemporal dementia. Brain 2005;128:1996-2005.

161 Mimura M, White RF, Albert ML: Corticobasal degeneration: neuropsychological and clinical correlates. J Neuropsychiatry Clin Neurosci 1997;9:94-98.

162 Frattali CM, Grafman J, Patronas N, Makhlouf F, Litvan I: Language disturbances in corticobasal degeneration. Neurology 2000;54:990-992.

163 Dubois B, Slachevsky A, Litvan I, Pillon B: The FAB: a Frontal Assessment Battery at bedside. Neurology 2000;55:1621-1626.

164 Graham NL, Bak TH, Hodges JR: Corticobasal degeneration as a cognitive disorder. Mov Disord 2003;18:1224-1232.
165 Graham NL, Zeman A, Young AW, Patterson K, Hodges JR: Dyspraxia in a patient with corticobasal degeneration: the role of visual and tactile inputs to action. J Neurol Neurosurg Psychiatry 1999;67:334-344.

166 Pillon B, Blin J, Vidailhet M, Deweer B, Sirigu A, Dubois B, Agid Y: The neuropsychological pattern of corticobasal degeneration: comparison with progressive supranuclear palsy and Alzheimer's disease. Neurology 1995;45:1477-1483.

167 Le Rhun E, Richard F, Pasquier F: Natural history of primary progressive aphasia. Neurology 2005;65:887-891.

168 Litvan I, Cummings JL, Mega M: Neuropsychiatric features of corticobasal degeneration. J Neurol Neurosurg Psychiatry 1998;65:717-721.

169 Soliveri P, Monza D, Paridi D, Carella F, Genitrini S, Testa D, Girotti F: Neuropsychological follow-up in patients with Parkinson's disease, striatonigral degeneration-type multisystem atrophy, and progressive supranuclear palsy. J Neurol Neurosurg Psychiatry 2000;69:313-318.

170 Groschel K, Hauser TK, Luft A, Patronas N, Dichgans J, Litvan I, Schulz JB: Magnetic resonance imaging-based volumetry differentiates progressive supranuclear palsy from corticobasal degeneration. Neuroimage 2004;21:714-724.

171 Sobrido MJ, Abu-Khalil A, Weintraub S, Johnson N, Quinn B, Cummings JL, Mesulam MM, Geschwind DH: Possible association of the tau $\mathrm{H} 1 / \mathrm{H} 1$ genotype with primary progressive aphasia. Neurology 2003; 60:862-864

172 Arvanitakis Z, Wszolek ZK: Recent advances in the understanding of tau protein and movement disorders. Curr Opin Neurol 2001;14:491-497.

173 Feany MB, Mattiace LA, Dickson DW: Neuropathologic overlap of progressive supranuclear palsy, Pick's disease and corticobasal degeneration. J Neuropathol Exp Neurol 1996;55:53-67.

174 Moretti R, Torre P, Antonello RM, Cattaruzza T, Cazzato G, Bava A: Rivastigmine in frontotemporal dementia: an open-label study. Drugs Aging 2004;21:931-937.

175 Geula C, Darvesh S: Butyrylcholinesterase, cholinergic neurotransmission and the pathology of Alzheimer's disease. Drugs Today (Barc) 2004;40:711-721.

176 Gomez-Ramos P, Moran MA: Ultrastructural localization of butyrylcholinesterase in senile plaques in the brains of aged and Alzheimer disease patients. Mol Chem Neuropathol 1997;30:161-173. 